\title{
Predatory role of the commander squid Berryteuthis magister in the eastern Bering Sea: insights from stable isotopes and food habits
}

\author{
Mary E. Hunsicker ${ }^{1,3, *}$, Timothy E. Essington ${ }^{1}$, Kerim Y. Aydin ${ }^{2}$, Bryan Ishida ${ }^{1}$ \\ ${ }^{1}$ School of Aquatic and Fishery Sciences, University of Washington, Box 355020, Seattle, Washington 98103, USA \\ ${ }^{2}$ Alaska Fisheries Science Center, NOAA Fisheries, 7600 Sand Point Way N.E., Building 4, Seattle, Washington 98115, USA \\ ${ }^{3}$ Present address: College of Oceanic and Atmospheric Sciences, Oregon State University, \\ 104 Ocean Administration Building, Corvallis, Oregon 97331, USA
}

\begin{abstract}
Squid are an important component of many marine food webs, and they can impact other species through predation and competition. However, quantifying their influence on other food web components requires knowledge of their trophic position and trophic ontogeny, which are unknown in many ecosystems. The eastern Bering Sea (EBS) is a highly productive region that supports large commercial fisheries, and a modicum of knowledge exists on the ecological role of squid in this region. We combined stomach content and stable isotope analyses of muscle tissue $\left(\delta^{15} \mathrm{~N}\right.$ and $\delta^{13} \mathrm{C}$ ) to identify the feeding ecology of the commander squid Berryteuthis magister in the EBS continental slope ecosystem. We also use a novel methodology to elucidate potential finer-scale variation in squid trophic ecology by reconstructing feeding chronologies of individual B. magister from concentric eye lens layers. Our analyses indicate that the position of $B$. magister in the EBS food web increases by approximately 1 trophic level between juvenile and adult stages. Also, in contrast to many squid species, we found that predation by $B$. magister is not constrained by prey body size and that $B$. magister are more likely to share prey resources with commercially valuable fishes, particularly walleye pollock Theragra chalcogramma, than to prey upon their juvenile stages. Further, the reconstructed feeding chronologies indicate substantial variability in squid feeding patterns that are not captured on the time scales of the conventional analyses. Together, the findings of this study contribute to a better understanding of the ecological role of $B$. magister and the trophic linkages and energy flow within the EBS food web.
\end{abstract}

KEY WORDS: Squid · Trophic interactions · Stable isotopes $\cdot$ Prey size spectra $\cdot$ Feeding chronology Berryteuthis magister · Eastern Bering Sea

Resale or republication not permitted without written consent of the publisher

\section{INTRODUCTION}

Squid occupy a central position in marine food webs. They are a valuable prey resource for fishes, seabirds, and marine mammals and are also voracious predators of crustaceans, squid, and fishes (Clarke 1996, Croxall \& Prince 1996, Klages 1996, Smale 1996). Because of their high feeding rates and generalist feeding strategy, squid can potentially exert trophodynamic control on the recruitment of the early life stages of fishes (Dawe 1988, Rodhouse \& Nigmatullin 1996, Hunsicker
\& Essington 2008). Moreover, their importance in food webs may be changing in response to fisheriesinduced alterations to trophic structures and climate change (e.g. Humboldt squid Dosidicus gigas, Field et al. 2007, Zeidberg \& Robinson 2007). An understanding of the potential impacts of these changes on marine systems is presently hampered by gaps in our understanding of the ecological role of squid.

As in many ecosystems, we have a limited understanding of the trophic roles of squid in the eastern Bering Sea (EBS). The EBS is a highly productive 
ecosystem that supports some of the world's largest commercial fisheries as well as the production of species of conservation interest (National Research Council, NRC 1996). Over the past few decades, the structure of this ecosystem has shifted in response to human activities and changing environmental conditions (NRC 1996, Alexander 1999, Springer 1999). To understand how anthropogenic and natural forcing may impact the trophic linkages and energy flow within this system, much effort has focused on identifying the trophic relationships of commercial and conservation species. However, the ecological roles of non-target species, such as mesopelagic squid, have been understudied.

The goal of our work is to provide a better understanding of the trophic ecology of the commander squid Berryteuthis magister (Cephalopoda, Gonatidae), by examining its predatory role in the EBS continental slope ecosystem. B. magister is the most abundant squid species in the EBS (Radchenko 1992, Sinclair \& Stabeno 2002), where it inhabits the outer edge of the continental shelf and slope, reaching depths of $1500 \mathrm{~m}$ (Nesis 1998). Juveniles mostly occur in midwater at mesopelagic depths, while adults mainly inhabit the bottom layers in the upper bathyal zone (Nesis 1997, 1998, Arkhipkin et al. 1998): both life stages undertake diel vertical migrations with night ascent (Gorbatenko et al. 1995, Arkhipkin et al. 1998). Previous work indicates that $B$. magister is a key component in the food webs of the western and central Bering Sea (Frost \& Lowry 1981, Lowry et al. 1982, Radchenko 1992, Nesis 1997, 1998, Aydin et al. 2007). Food web models of EBS also indicate that squid are an important link in the transfer of energy from lower to higher trophic levels (Aydin et al. 2007). Further, squid can be important predators or competitors of juvenile stages of gadoids and other high trophic level fishes (Hunsicker \& Essington 2006, 2008, Field et al. 2007), and commercially valuable gadoid fishes, particularly walleye pollock Theragra chalcogramma, dominate the fish biomass in the EBS.

Knowledge of the trophic ontogeny of Berryteuthis magister and the size-structure of their feeding relationships is paramount for determining their ecological role. Body size dictates predator-prey relationships in many marine systems (Lundvall et al. 1999, Jennings et al. 2001, Shin \& Cury 2004), and squid exhibit ontogenetic, size-dependent patterns in predation (Collins \& Pierce 1996, Lordan et al. 1998, Hunsicker \& Essington 2006). By identifying the prey size spectra of $B$. magister, we can determine the prey species and sizes that are vulnerable to squid predation. This information is valuable for assessing the potential consequences of $B$. magister feeding habits and for exploring how the strength of their trophic interactions may change if predator and (or) prey body sizes are altered by ecosystem perturbations (Woodward et al. 2005).

Identifying the feeding habits of squid is challenging owing to their feeding behavior and rapid digestion of prey (Nixon 1987, Dawe et al. 1997). Squid masticate their food and therefore may only consume a portion of their prey at feeding. Here, we attempted to overcome those challenges by using multiple pathways to characterize the trophic role of Berryteuthis magister. We used traditional stomach content analyses to identify prey taxa, estimate the prey size spectra of $B$. magister, and determine how prey composition changes with squid ontogeny. Stomach content analysis provides high detail on prey contents; however, due to squid feeding attributes, it does not provide a good assessment of their trophic positions (i.e. the average levels, relative to primary producers, at which an organism feeds). Also, this analysis only provides information on an animal's last feeding event and reveals no information on the feeding habits of sampled predators with empty or unidentifiable stomach contents. In contrast, stable isotope ratios $\left({ }^{15} \mathrm{~N}:{ }^{14} \mathrm{~N}\right.$ and $\left.{ }^{13} \mathrm{C}:{ }^{12} \mathrm{C}\right)$ of animal tissues can provide more precise estimates of long-term average trophic position. These ratios provide less detail on digested prey items, but they provide a measure of feeding that is integrated over several weeks or months (Ruiz-Cooley et al. 2006). Stable isotope analyses have been a valuable tool for investigating the trophic ecology of squid (Takai et al. 2000, Cherel \& Hobson 2005, Ruiz-Cooley et al. 2006, 2010, Parry 2008, Cherel et al. 2009). We used stable isotopes as a complementary method to identify ontogenetic shifts in B. magister trophic position and to evaluate their trophic position with respect to marine fishes inhabiting the EBS.

In addition to these 2 conventional approaches, we further explored whether reconstructed feeding chronologies from concentric eye lens layers can be used as an alternative method to evaluate the ecological role of Berryteuthis magister. Feeding chronologies from squid hard parts, such as eye lenses (Parry 2003) and gladii (Ruiz-Cooley et al. 2010) are a valuable tool because they offer several measures of individual feeding events that are integrated over time scales intermediate to stomach content and stable isotope analysis of muscle tissue. For instance, fish lens cells are nearly ametabolic because most of the cells (all but those in the youngest, differentiating layer) lack the cellular functions of protein synthesis and catabolism (Wistow \& Piatigorsky 1988, Nicol 1989, Horwitz 1992, Dove 1999). The same is likely to be true for squid eye lenses (see West et al. 1995); thus, with little to no protein turnover in the lens cells, isotope signatures laid down in the lens layers may essentially be locked in place during their formation (Parry 2003). From a sam- 
pling standpoint, reconstructed feeding chronologies could improve our ability to evaluate the feeding ecology of squid life stages or species that are difficult to capture with traditional sampling gear. Similarly, feeding chronologies would allow us to explore the trophic ontogeny of squid with far fewer samples than would be needed for stomach content analysis or muscle tissue stable isotope analysis.

In this study, we addressed the following questions to better understand the role of Berryteuthis magister in the EBS continental slope ecosystem. Do B. magister exhibit ontogenetic shifts in prey composition and trophic position? Are the predation patterns of $B$. magister dictated by size constraints? Is there evidence of predation by $B$. magister on higher trophic level fishes, including species of commercial value? Are there variations in B. magister trophic patterns revealed by feeding chronologies that are not captured by the conventional analyses of predator food

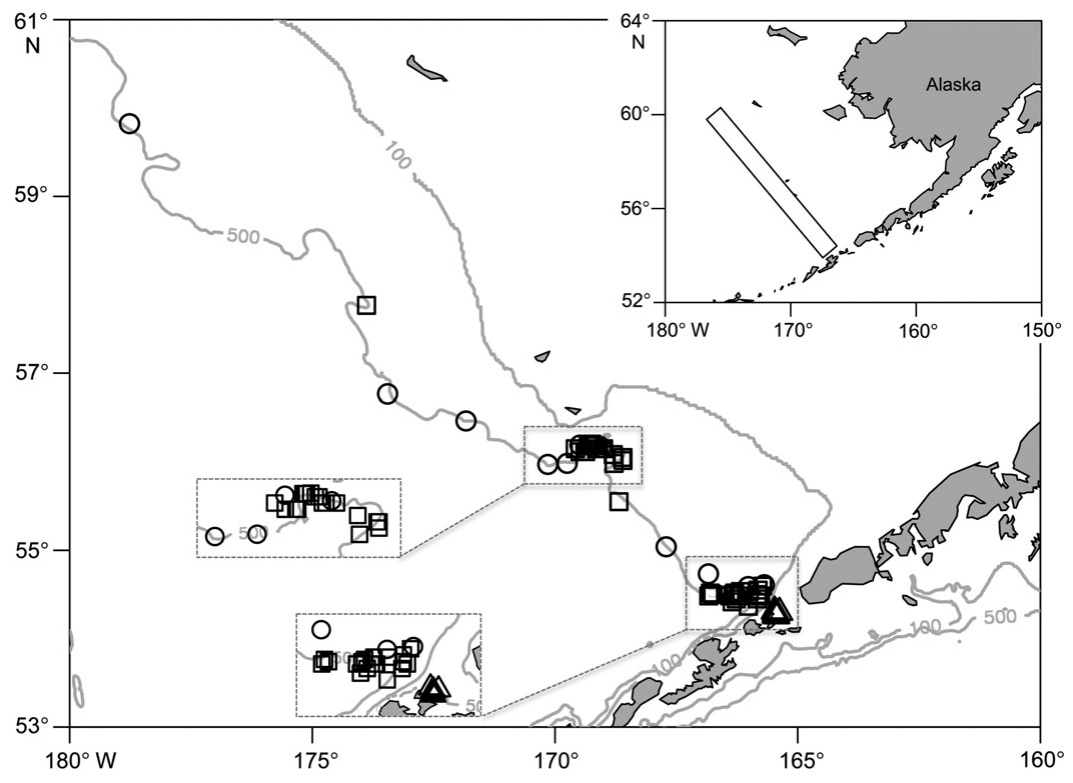

Fig. 1. Capture locations of Berryteuthis magister in the eastern Bering Sea. (O) Summer 2004, $(\square)$ winter 2007, and $(\Delta)$ summer 2007. The 100 and $500 \mathrm{~m}$ depth contours are shown. The insets (dotted lines) provide a closer view of the multiple capture locations that are in proximity to each other. The rectangle in the inset map of Alaska indicates the region of the capture locations within the eastern Bering Sea habits? Our findings provide a strong foundation for identifying the potential influence of $B$. magister on other nekton through direct and indirect food web pathways.

\section{MATERIALS AND METHODS}

Sample collection. Berryteuthis magister were collected near the edge of the continental shelf and slope in the EBS (Fig. 1). Squid were sampled during summer and winter seasons with the intention of collecting a wide size range to account for seasonal and ontogenetic shifts in diet composition. Summer samples were collected through research surveys conducted by NOAA Fisheries, Alaska Fisheries Science Center (NOAA - AFSC; June to July 2004) and the University of Washington (August 2007). The summer samples were collected mainly from daytime bottom trawls (cod end mesh size $13 \mathrm{~mm}$ ) at discrete depths ranging from 330 to $755 \mathrm{~m}$
Table 1. Berryteuthis magister. Mean capture depths and body sizes analyzed for stomach contents $(\mathrm{n}=$ sample size). The percent frequency of occurrence of $B$. magister prey items is shown by season and year, and all years combined. The scientific names of prey identified from the stomach contents of $B$. magister and the numbers of otoliths and beaks identified to each prey are also shown by season and year

\begin{tabular}{|c|c|c|c|c|}
\hline & $\begin{array}{c}\text { All years } \\
\mathrm{n}=697\end{array}$ & $\begin{array}{c}\text { Summer } 2004 \\
\mathrm{n}=107\end{array}$ & $\begin{array}{c}\text { Winter } 2007 \\
\mathrm{n}=336\end{array}$ & $\begin{array}{c}\text { Summer } 2007 \\
\mathrm{n}=254\end{array}$ \\
\hline Capture depth (m) & $394 \pm 103$ & $393 \pm 92$ & $466 \pm 90$ & $321 \pm 61$ \\
\hline Dorsal mantle length (mm) & $219 \pm 97$ & $172 \pm 74$ & $227 \pm 127$ & $230 \pm 47$ \\
\hline Body mass (g) & $360 \pm 216$ & $243 \pm 249$ & $338 \pm 210$ & $389 \pm 192$ \\
\hline \multicolumn{5}{|l|}{ Frequency of occurrence (\%): } \\
\hline Fish & 40.75 & 20.56 & 42.56 & 46.85 \\
\hline Squid & 19.94 & 17.76 & 16.37 & 25.59 \\
\hline Crustacean & 7.32 & 14.95 & 2.68 & 10.24 \\
\hline Empty & 30.70 & 34.58 & 34.52 & 24.02 \\
\hline Unidentifiable prey only & 13.20 & 19.63 & 8.63 & 16.54 \\
\hline \multicolumn{5}{|c|}{$\begin{array}{l}\text { Number of identified hard parts: } \\
\text { Fishes (otoliths) }\end{array}$} \\
\hline Leuroglossus schmidti & 309 & 3 & 214 & 92 \\
\hline Stenobrachius leucopsarus & 7 & 2 & 0 & 5 \\
\hline Lampanyctus jordani & 2 & 0 & 2 & 0 \\
\hline Benthabella dentata & 2 & 2 & 0 & 0 \\
\hline Post-larval liparid & 1 & 1 & 0 & 0 \\
\hline Cyclopteridae sp. & 1 & 0 & 0 & 1 \\
\hline Theragra chalcogramma & 1 & 1 & 0 & 0 \\
\hline \multicolumn{5}{|l|}{ Squid (beaks) } \\
\hline Berryteuthis magister & 17 & 2 & 12 & 3 \\
\hline Gonatopsis borealis & 4 & 0 & 4 & 0 \\
\hline B. magister/G. borealis & 36 & 0 & 17 & 19 \\
\hline Gonatus sp. & 46 & 30 & 11 & 5 \\
\hline Gonatus onyx & 9 & 0 & 0 & 9 \\
\hline $\begin{array}{l}\text { Gonatus madokai / } \\
\text { Gonatus middendorffi }\end{array}$ & 6 & 1 & 4 & 1 \\
\hline
\end{tabular}


in summer 2004 and 200 to $400 \mathrm{~m}$ in summer 2007 (Table 1). The winter samples were collected through the North Pacific Groundfish Observer Monitoring Program (January to March 2007). These squid were randomly sampled by observers from pelagic trawls primarily targeting pollock (cod end mesh size $\sim 75$ to $115 \mathrm{~mm}$ ) and fishing at discrete depths ranging from 350 to $985 \mathrm{~m}$ (Table 1). All samples were frozen and stored at $-20^{\circ} \mathrm{C}$ after collection. Once defrosted, squid dorsal mantle lengths were recorded to the nearest $1 \mathrm{~mm}$, and total wet weights were measured to the nearest $0.1 \mathrm{~g}$.

General diet analysis. Approximately 700 Berryteuthis magister collected during summer 2004, summer 2007, and winter 2007 were dissected for stomach content analysis (Table 1). Prey items of $B$. magister were identified from undigested hard parts found in squid stomachs. Digested fish were identified from otoliths, scales, and bones, and squid prey were identified from beaks, gladii, hooks, and statoliths (Vinogradov \& Noskov 1979, Santos \& Haimovici 1998, Hunsicker \& Essington 2006). Crustaceans were identified by eyes, appendages, mandibles, and exoskeletons (Karpov \& Cailliet 1978, Santos \& Haimovici 1998). Prey items were identified using a dissection microscope and were initially grouped by visual identification of hard parts and soft tissues as fish, squid, crustaceans, or unknown. We recorded the wet weights of squid stomach masses and individual prey items. We also noted freshly digested prey items and excluded them from our analyses to omit bias due to predation inside trawl nets. Prey hard parts were stored dry or in $80 \%$ ethanol for subsequent taxonomic classification. The diet composition of $B$. magister was quantified by calculating the percent frequency of occurrence of each prey item in the squid stomach contents. Squid masticate their food; thus it is nearly impossible to quantify their prey composition by percent number or mass.

We used logistic regression analysis to detect ontogenetic shifts in the diet of Berryteuthis magister. Separate analyses were conducted to gauge the influence of body size on the frequency of occurrence of prey categorized as fish, squid, or crustacean. This analysis relates the probability of occurrence of a specific prey item (fish, squid or crustaceans) to the mantle lengths of $B$. magister collected in the summer and winter seasons. We evaluated the ontogenetic shifts in diets during both seasons by calculating the $95 \%$ confidence intervals of the slope. We then repeated this analysis to examine whether $B$. magister might also exhibit dietary shifts related to capture depth or location. We simply replaced the explanatory variable with capture depth and latitude.

Prey size spectrum. Fish and squid consumed by Berryteuthis magister during summers of 2004 and 2007 and winter 2007 were identified to lowest possi- ble taxon by comparing the morphological features and size ratios of digested fish otoliths and squid beaks to those in the reference collection of the National Marine Mammal Laboratory (NMML - NOAA - AFSC). The sizes of fish and squid prey were then estimated using species-specific otolith length to body length relationships and lower rostral beak length (LRL) to mantle length relationships, respectively (Zeppelin et al. 2004, Gudmundson et al. 2006, W. Walker unpubl. data). Note that the beaks of B. magister and Gonatopsis borealis with LRL of $<1 \mathrm{~mm}$ are nearly indistinguishable. Similarly, the small beaks (LRL $<1 \mathrm{~mm}$ ) of Gonatus species as well as Gonatus middendorffi and G. madokai are difficult to discern from each other. Thus, beaks with LRLs $<1 \mathrm{~mm}$ were identified to coarser taxonomic groups, i.e. B. magister/G. borealis, Gonatus sp., or G. middendorffi/G. madoakai.

We used quantile regression to analyze the relationship between Berryteuthis magister mantle lengths and their prey sizes. The 10th and 90th quantiles were used as the upper and lower bound regression quantiles in this analysis (Rogers 1992, Scharf et al. 1998). This technique has been used previously to estimate the relationship between squid body size and the minimum or maximum sizes of their prey (Hunsicker \& Essington 2006). Further, we used the Student's $t$-test to determine if there was a significant difference in upper bound regression lines of fish and squid prey. A difference in slope values may indicate that maximum prey size is dependent upon the prey type (Scharf et al. 2000, Juanes 2003).

Stable isotope analyses. To determine the trophic position of Berryteuthis magister in the EBS, we analyzed $\delta^{15} \mathrm{~N}$ and $\delta^{13} \mathrm{C}$ signatures of squid mantle muscle tissue. The muscle tissue of squid reflects predator feeding habits (Stowasser et al. 2006), and mantle tissue has been used to quantify the relative trophic position of squid in past studies (Takai et al. 2000, Parry 2008). A small portion ( 13 $\left.\mathrm{mm}^{3}\right)$ of tissue was excised from the mantles of 50 squid caught in summer 2004 and 50 squid collected in winter 2007 . We did not analyze the isotope signatures of squid collected during summer 2007. The tissue samples were dried at $64^{\circ} \mathrm{C}$, ground with mortar and pestle into a homogeneous powder, and weighed according to the guidelines of the Colorado Plateau Stable Isotope Laboratory (CPISL; www.mpcer.nau.edu/isotopelab/). Lipids were not removed from squid tissues prior to the stable isotope analysis. Lipids do not contain nitrogen and thus do not affect nitrogen isotope signatures, though variations in the lipid content within tissues can significantly influence $\delta^{13} \mathrm{C}$ values and hence bias the interpretation of the carbon isotope results (Kiljunen et al. 2006, Sweeting et al. 2006). However, the C:N ratios of the squid tissues analyzed in this study ranged 
between 3 and 3.5, indicating that the lipid content in these tissues was quite low (Kiljunen et al. 2006). For that reason, we expect that the $\delta^{13} \mathrm{C}$ values of $B$. magister muscle tissue would not be confounded by individual variation in lipid densities. The isotope analyses were conducted at the CPISL and were carried out in continuous-flow mode using a Thermo-Finnigan Delta ${ }^{\text {plus }}$ Advantage gas isotope-ratio mass spectrometer interfaced with a Costech Analytical ECS4010 elemental analyzer. Isotopic ratios are expressed using standard $\times$ notation, where $\delta^{15} \mathrm{~N}$ or $\delta^{13} \mathrm{C}=\left[\left(\mathrm{R}_{\text {sample }} /\right.\right.$ $\left.\left.R_{\text {standard }}\right)-1\right] \times 1000$ and $R$ is the ratio of ${ }^{15} \mathrm{~N}:{ }^{14} \mathrm{~N}$ or ${ }^{13} \mathrm{C}:{ }^{12} \mathrm{C}$ in the sample and standards, respectively. Atmospheric nitrogen and Pee Dee Belemnite were used as nitrogen and carbon standards, respectively. The data were normalized using 4 internationally accepted isotope reference standards (IAEA CH6, CH7, N1, and N2). External precision on laboratory standards was $\pm 0.20 \%$ or better for $\delta^{15} \mathrm{~N}$ and $\pm 0.10 \%$ or better for $\delta^{13} \mathrm{C}$. We used the Spearman rank correlation test to determine whether the $\delta^{15} \mathrm{~N}$ and $\delta^{13} \mathrm{C}$ signatures of $B$. magister muscle tissue differed by capture depth or location. Regression analysis was also done to evaluate the relationship between squid mantle lengths and the isotopic signatures of muscle tissues.

To evaluate the trophic level of Berryteuthis magister within a broader ecosystem context, we compared $\delta^{15} \mathrm{~N}$ signatures of juvenile $(<120 \mathrm{~mm}$ dorsal mantle length) and adult squid ( $\geq 120 \mathrm{~mm}$, i.e. size at maturation; Nesis 1997) collected in summer 2004 to the $\delta^{15} \mathrm{~N}$ signatures of the dorsal white muscle tissue of commercially important fishes inhabiting the eastern Bering Sea (C. Kurle, E. Sinclair, A. Edwards, C. Gudmundson unpubl. data). The fishes were collected in summer 2005 through the North Pacific Groundfish Observer Monitoring Program. The fishes were captured at different times and locations than the B. magister samples analyzed in this study. We cannot show the specific capture locations of the fishes because the observer data could not be aggregated in a manner that protects the confidentiality of private commercial fishing interests (see www.afsc.noaa.gov/FMA/fma database.htm). We compared the nitrogen isotopes of $B$. magister to the following fish species: juvenile and adult walleye pollock Theragra chalcogramma, adult yellowfin sole Limanda aspera, adult northern rock sole Lepidopsetta polyxystra, adult flathead sole Hippoglossoides elassodon, adult arrowtooth flounder Atheresthes stomias, and adult Pacific cod Gadus macrocephalus. Again, lipids were not removed from fish tissues prior to stable isotope analysis; thus comparisons between squid and fish $\delta^{13} \mathrm{C}$ signatures could be biased due to differences in lipid content. For that reason, we limited our comparisons between squid and fishes to $\delta^{15} \mathrm{~N}$ signatures, which are not affected by lipids (Kiljunen et al. 2006). Our comparisons were also restricted to the summer season because at the time of our study the only available estimates of fish $\delta^{15} \mathrm{~N}$ signatures were from fishes captured during this period. With the exception of pollock, we were not able to stratify the $\delta^{15} \mathrm{~N}$ signatures of the fishes by size or life stage because the fishes were of similar sizes. Box plot graphs of the summer $\delta^{15} \mathrm{~N}$ values of $B$. magister and fishes were created to compare their trophic positions.

Feeding chronology through eye lens analysis. Following the methods of Parry (2003), we evaluated the squid feeding chronology by examining changes in isotopic signatures $\left(\delta^{15} \mathrm{~N}\right.$ and $\left.\delta^{13} \mathrm{C}\right)$ as a function of eye lens radius. The squid eye is a spherical structure comprised of distal and proximal lenses and has a recognizable layering of thin tissue. Similar to many fishes, squid exhibit chronological deposition of concentric layers to the outer surface of their eye lens as they grow (Nicol 1989, West et al. 1995, Dove 1999). The center of the lens contains the oldest layer, whereas the youngest layer lies on the outer rim (Fig. 2). The proximal lens is the larger of the 2 lenses, and we analyzed the isotopic signatures of this tissue to reconstruct the feeding chronologies of 20 summer squid (year 2004 only) and 21 winter squid (year 2007). Preparations for isotope analysis proceeded in 3 steps. First, we cleaved the eyeball of an adult squid while it was thawing to isolate the proximal lens and measured the longest width of this lens using an ocular micrometer on a dissecting microscope at $8 \times$ power. Mantle lengths of the squid ranged from 220 to $310 \mathrm{~mm}$, and total widths of their proximal lens ranged from 6.5 to $10.5 \mathrm{~mm}$. Second, a segment of tissue layers was

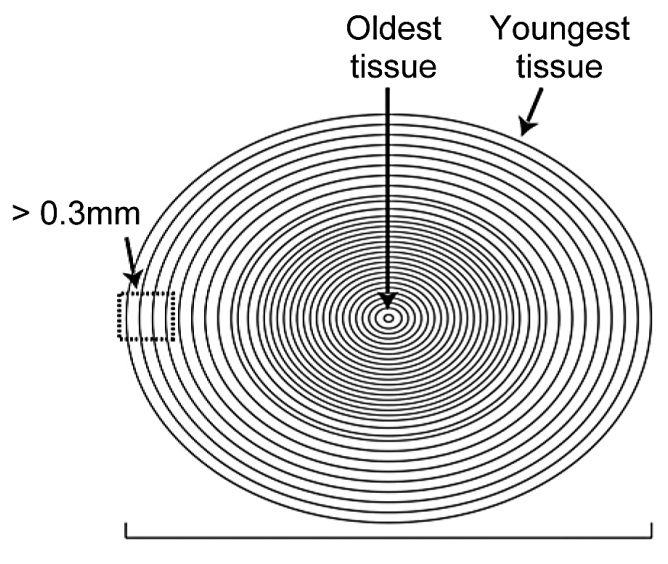

\section{$6.5-10.5 \mathrm{~mm}$}

Fig. 2. Berryteuthis magister. Squid proximal eye lens. The youngest tissue lies on the outer edge of the lens, and the oldest tissue is in the center of the lens. The width of the eye lenses examined in our study ranged between 6.5 and $10.5 \mathrm{~mm}$. Six to 11 lens segments, each $>0.3 \mathrm{~mm}$ in width, were extracted from the eye lenses for stable isotope analysis.

Each segment contained multiple individual lens layers 
excised from the outermost edge of the lens, rinsed with distilled water, and set aside for subsequent preparation. As it was nearly impossible to remove single layers of lens tissue, we removed relatively precise fixed groups of lens layers to get an approximation of intermediate feeding chronology (Fig. 2). To ensure that there was a sufficient amount of tissue for the isotope analyses, each segment was $>0.3 \mathrm{~mm}$ in width. The number of segments extracted from an individual eye lens ranged between 6 and 11 among squid samples due to size differences of the squid eyes. Third, upon removal of each segment, the width of the proximal lens was re-measured. To avoid contamination, the scalpels and forceps used to separate and measure the individual lens layers were cleaned with ethanol following each excision. Also, if the proximal lens began to dry, making it more difficult to excise lens segments, we rinsed the eye lens with distilled water. The second and third steps were repeated until the final lens segment at the center of the squid eye was removed. All lens segments were dried, ground, weighed (0.6 to $1.2 \mathrm{mg}$ ), and analyzed for $\delta^{15} \mathrm{~N}$ and $\delta^{13} \mathrm{C}$ signature in the same manner as the Berryteuthis magister mantle muscle tissue.

To evaluate the trophic record of individual Berryteuthis magister, we related the isotopic signatures of the lens segments to particular squid body sizes. First, a regression for squid eye lens width to squid mantle length was developed from the proximal lenses of 50 summer squid (year 2004 only) and 50 winter squid (year 2007) of various body sizes. Squid mantle lengths ranged from approximately 65 to $135 \mathrm{~mm}$, and total widths of the proximal lenses ranged from 2.5 to $10.5 \mathrm{~mm}$. For each lens segment that was analyzed for isotopic signatures, we used these regressions to predict the approximate length range of the squid at the time a lens segment was laid down. Next, we generated coarse estimates of the time scales over which the lens segments were laid down. Length at age was estimated for individual B. magister captured during summer 2004 (Drobny 2008); however, it was not possible to fit a growth model to the data because the estimates were highly variable. This precluded us from using growth curves to back-calculate the age of squid to the time when the tissues were formed. Thus, we instead calculated the time over which the prey isotope signatures were integrated within the lens segment by dividing the estimated age of an individual squid (Drobny 2008 ; 120 to 180 d) by the number of lens segments examined. Age estimates of B. magister were only available for the summer 2004 samples; therefore, we used the average integration time estimated from these samples to back-calculate the approximate time at which the first lens segments of winter- and summer-caught squid were laid down.
We used multiple approaches to evaluate the observed patterns of squid feeding chronologies. Our intent was to first determine if the $\delta^{15} \mathrm{~N}$ signatures revealed by the individual chronologies exhibited the monotonic increase with mantle length that is often observed from isotopic signatures of squid muscle tissue (e.g. Parry 2008, Cherel et al. 2009). To this end, we regressed the $\delta^{15} \mathrm{~N}$ values of the lens segments on the predicted mantle lengths and then quantified the frequency of individual records that demonstrated positive slope values that were at least marginally statistically significant $(p<0.10)$ and those that did not. Next, we estimated the average slopes of individual eye lens $\delta^{15} \mathrm{~N}$ and $\delta^{13} \mathrm{C}$ values among and within seasons by fitting linear mixed effects models to the isotope data. The $\delta^{15} \mathrm{~N}$ or $\delta^{13} \mathrm{C}$ value was the response variable and squid mantle length and individual squid ID were the fixed and random effects, respectively. We also determined if the average relationship of lens $\delta^{15} \mathrm{~N}$ and $\delta^{13} \mathrm{C}$ values and estimated squid mantle lengths differed between seasons by adding season and season $\times$ mantle length as fixed effects terms to the linear mixed effects models. The interaction term is useful for identifying whether the average slopes differed between winter and summer seasons. We fit the models using the nlme package in $\mathrm{R}$ version 2.10.2 (R Development Core Team 2010). Lastly, we examined whether the average slopes of eye lens $\delta^{15} \mathrm{~N}$ and $\delta^{13} \mathrm{C}$ values among the individuals were similar to the slopes estimated from muscle tissue analysis.

\section{RESULTS}

\section{General diet analysis}

The mantle lengths of the summer 2004 and summer 2007 squid samples ranged from 62 to $334 \mathrm{~mm}$ and 90 to $335 \mathrm{~mm}$, respectively, and the winter 2007 samples ranged from 100 to $335 \mathrm{~mm}$ (Table 1). Of all of the stomachs analyzed, $56 \%$ contained contents that were identifiable to coarse taxonomic groupings (i.e. fish, squid, or crustacean), $13 \%$ contained only unidentifiable prey items, and $31 \%$ were empty (Table 1 ). The percent occurrence of fish in summer and winter Berryteuthis magister stomach contents was the highest of all prey items, followed by squid and crustaceans. The percent occurrence of fish in squid diets was as high as $47 \%$. The frequencies of empty B. magister stomachs or those with only unidentifiable prey items were relatively similar across summer and winter seasons (Table 1).

Results of the logistic regression analysis indicated that Berryteuthis magister underwent an ontogenetic shift in diet composition. The consumption of fish and 
squid by $B$. magister increased with mantle length, while the consumption of crustaceans decreased. This ontogenetic shift was evident during the summer (years 2004 and 2007 combined) and winter (year 2007) seasons (Fig. 3). The regression analysis highlighted the substantial frequency $(>0.10)$ of piscivory by $B$. magister over all body sizes. In the summer, the median estimates of the probability of piscivory increased from 10 to $65 \%$ from the smallest to largest observed squid body sizes. For winter, the median estimates ranged from $31 \%$ for squid at mantle lengths of $130 \mathrm{~mm}$ to $51 \%$ for the largest size squid. The regression analysis further revealed a seasonal difference in the pattern of piscivory by $B$. magister with capture
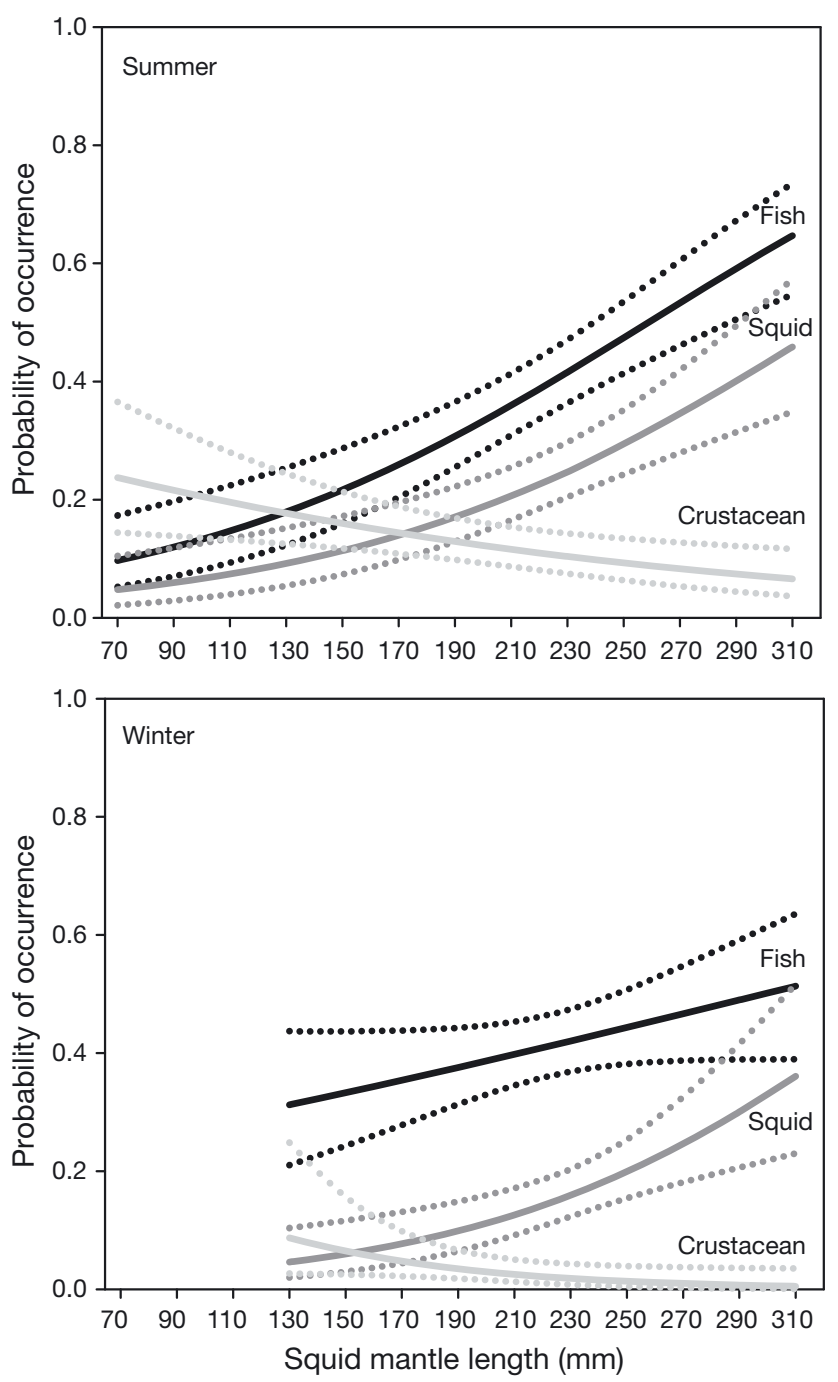

Fig. 3. Berryteuthis magister. Predicted probability of consumption of fish (black lines), squid (dark gray lines), and crustaceans (light gray lines) by B. magister at different mantle lengths. Logistic regression analyses were conducted for squid collected in summer (2004 and 2007 combined) and winter (2007). The 5th and 95th confidence intervals (dotted lines) are shown depth (data not shown). The median estimates of the probability of piscivory for summer B. magister decreased from 36 to $4 \%$ over the primary capture depths (i.e. mean $\pm 1 \mathrm{SD} ; 250-450 \mathrm{~m}$ ). In contrast, the frequency of piscivory by winter $B$. magister was higher at deeper capture depths and gradually declined with increasing depth: the median estimates of the probability of piscivory ranged from 54 to $40 \%$ over the primary capture depths (i.e. mean $\pm 1 \mathrm{SD}$; 350 to $550 \mathrm{~m}$ ). The consumption of squid by B. magister in relation to capture depth followed the same trends as those described for fish. The median estimate of the probability of squid consumption by $B$. magister declined with capture depth from 42 to $8 \%$ in the summer and from 23 to $11 \%$ in the winter. The frequency of consumption of crustaceans increased slightly from 10 to $16 \%$ with summer capture depths and was $<4 \%$ across all winter capture depths. We did not observe any meaningful shifts in the diets of $B$. magister with respect to latitude at capture.

Identification of digested hard parts revealed that Berryteuthis magister specimens preyed upon deepwater slope fishes and a variety of squid species, including conspecifics. The percent occurrence of otoliths and statoliths in non-empty $B$. magister stomachs was 16 and $9 \%$, respectively. We identified a total of 323 otoliths and 118 statoliths, but the northern smooth-tongue Leuroglossus schmidti was by far the most common prey identified from the stomach contents (Table 1), representing $95 \%$ of the total number of identified otoliths. The remaining otoliths belonged to northern lampfish Stenobrachius leucopsaurus, brokenline lanternfish Lampanyctus jordani, northern pearleye Benthabella dentata, lumpsuckers (Cyclopteridae sp.), snailfishes (liparids), and pollock Theragra chalcogramma. In contrast to the fish otoliths, the squid beaks consumed by $B$. magister were not dominated by a single taxonomic group (Table 1). Approximately $14 \%$ of the lower beaks were identified as $B$. magister, $7 \%$ were Gonatus onyx, and 3\% were Gonatopsis borealis. The coarser taxonomic grouping of Gonatus sp. represented $40 \%$ of the digested beaks whereas the B. magister/G. borealis and G. madokiai/ G. middendorffi groups represented 31 and $5 \%$ of the beaks, respectively.

\section{Prey size spectrum}

Quantile regression analysis of all prey sizes consumed by Berryteuthis magister during summers 2004 and 2007 and winter 2007 revealed a non-significant slope of the upper bound (90th quantile; $\mathrm{p}=1.000$ ) and lower bound regression lines (10th quantile, $p=0.339$; Fig. 4). However, the regression analysis of $B$. magister 

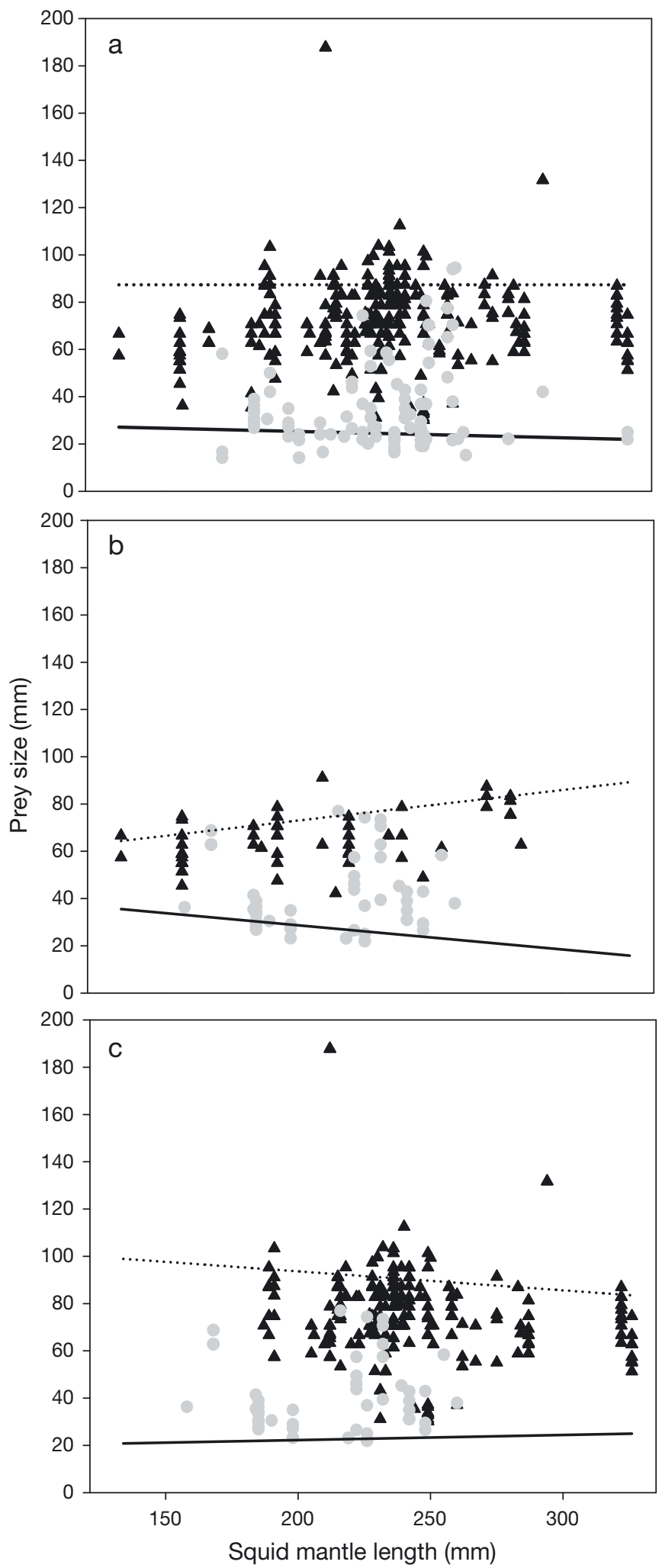

Fig. 4. Berryteuthis magister. Relationship between mantle length and estimated body sizes of consumed fish $(\boldsymbol{\Lambda})$ and squid (•) in (a) summer and winter, (b) winter only, and (c) summer only. Estimated quantile regression lines $t=0.10$ (solid lines) and 0.90 (dotted lines) are superimposed on the scatterplots prey sizes differed among seasons. We found non-significant upper (90th quantile, $\mathrm{p}=0.610$ ) and lower bound regression lines (10th quantile, $\mathrm{p}=0.071$ ) of summer prey sizes, whereas the winter prey sizes showed a positive, significant slope of the upper bound regression line (90th quantile, $\mathrm{p}<0.001$ ) and a nonsignificant lower bound (10th quantile, $\mathrm{p}=0.228$; Fig. 4). Also, non-significant trends were observed when we analyzed the prey size spectra of fish prey alone across both seasons (90th quantile, $p=1.000$; 10th quantile, $p=0.578$ ), whereas the size spectra of squid prey had positive, significant slopes for the upper (90th quantile, $\mathrm{p}=<0.001$ ) and lower (10th quantile, $\mathrm{p}=<0.001$ ) bound regression lines. Statistical comparisons of the regression lines for different prey types indicated that the slope of the upper bound of the squid prey size-predator size scatter plot was significantly greater than the slope for fish prey $(t=25.830$, df $=415, \mathrm{p}$ < 0.001). The minimum, maximum, and average sizes of squid consumed by $B$. magister were 15 , 95 , and $42 \pm 19 \mathrm{~mm}$, and the fish prey sizes typically ranged between 30 and $112 \mathrm{~mm}$ with an average size of $72 \pm 18 \mathrm{~mm}$.

\section{Stable isotope analyses}

The $\delta^{15} \mathrm{~N}$ signatures of squid muscle tissue indicated that the food web position of Berryteuthis magister spanned roughly 1 trophic level over the sampled size range (winter 2007: 105 to $310 \mathrm{~mm}$, summer 2004: 72 to $334 \mathrm{~mm}$ ). The $\delta^{15} \mathrm{~N}$ signatures of winter 2007 squid samples increased from approximately 11 to $15 \%$ over increasing squid mantle length (Fig. 5a). This range in $\delta^{15} \mathrm{~N}$ falls within the range of trophic fractionation (3 to $4 \%$; Minagawa \& Wada 1984). The $\delta^{15} \mathrm{~N}$ signatures of summer 2004 samples followed the same trend as the winter samples, ranging from approximately $10.50 \%$ for small squid to $13.45 \%$ for large squid. In contrast to the $\delta^{15} \mathrm{~N}$ signatures, the $\delta^{13} \mathrm{C}$ of winter 2007 and summer 2004 squid samples did not exhibit any distinguishable trends with body size (Fig. 5b). The $\delta^{13} \mathrm{C}$ values of winter samples ranged from -19.50 to $-21.20 \%$ and the summer samples ranged from -18.90 to $-21.25 \%$.

Overall, we found a significant, negative correlation between the $\delta^{13} \mathrm{C}$ signatures of Berryteuthis magister muscle tissue and latitude and depth at which they were captured (Table 2). This was found for both summer 2004 and winter 2007 samples. We did not find a significant correlation between the $\delta^{15} \mathrm{~N}$ of $B$. magister muscle tissue and the latitude at which squid were captured (Table 2). However, there was an overall significant, positive correlation between the $\delta^{15} \mathrm{~N}$ signatures of $B$. magister and capture depths (Table 2). The 

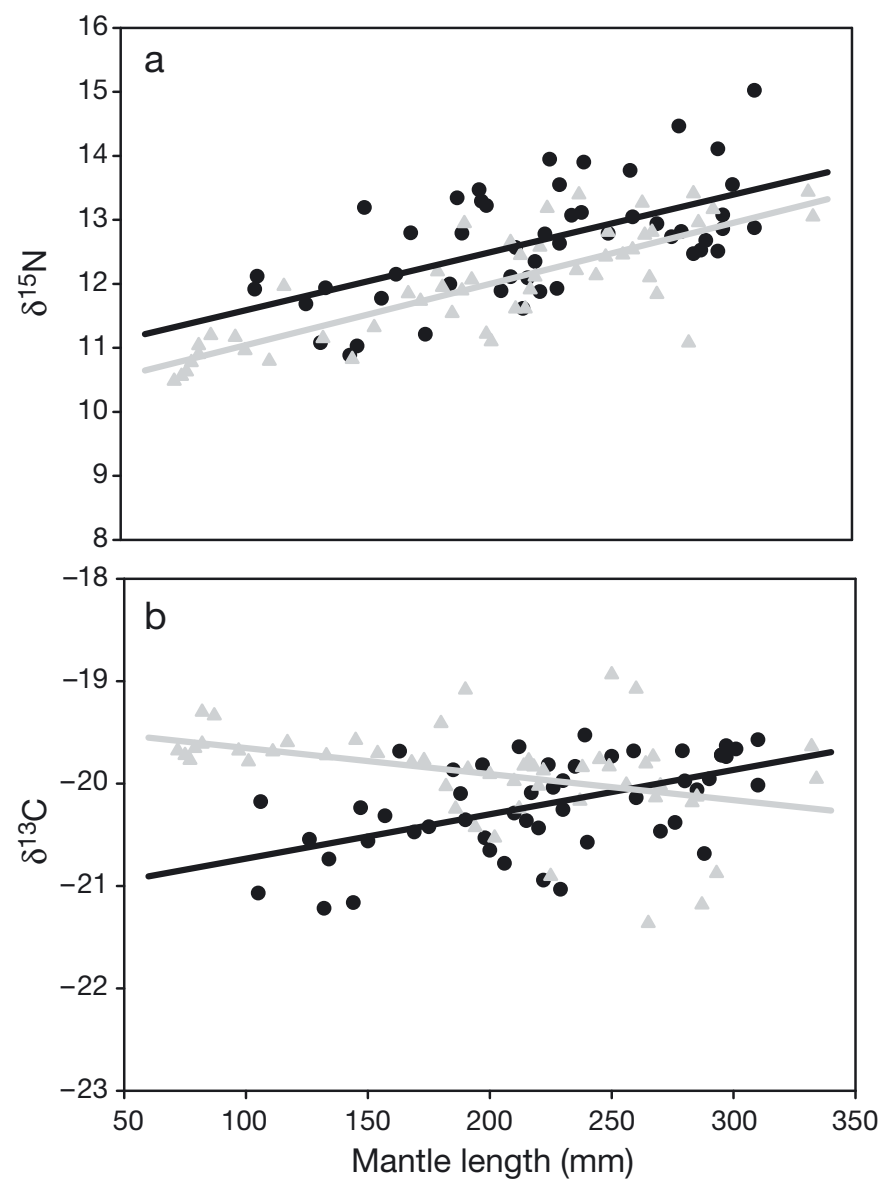

Fig. 5. Berryteuthis magister. (a) $\delta^{15} \mathrm{~N}$ and (b) $\delta^{13} \mathrm{C}$ signatures of mantle muscle tissue. The isotopic signatures were quantified from squid collected in summer $2004(\Delta)$ and winter 2007 $(\bullet)$. Equations of regression lines are: $y=10.071+0.010 x(r=$ $0.79, F=89.26, \mathrm{p}<0.001)$ and $y=10.69+0.009 x(\mathrm{r}=0.55, F=$ $25.18, \mathrm{p}<0.001)$ for $\delta^{15} \mathrm{~N}$ values of summer and winter muscle tissue versus mantle length, respectively, and $y=-19.40-$ $0.003 x(\mathrm{r}=0.50, F=8.53, \mathrm{p}=0.005)$ and $y=-21.16+0.004 x$ $(\mathrm{r}=0.55, F=20.38 \mathrm{p}<0.001)$ for $\delta^{13} \mathrm{C}$ values of summer and winter muscle tissue versus mantle length, respectively

average $\delta^{13} \mathrm{C}$ value of winter samples was significantly higher than the average summer $\delta^{13} \mathrm{C}$ value. The opposite trend was found for the $\delta^{15} \mathrm{~N}$ signatures of B. magister muscle tissue. The average $\mathrm{C}: \mathrm{N}$ mass ratios for summer 2004 and winter 2007 samples did not differ significantly between seasons (Table 2).

Comparisons between the isotopic signatures of squid and fish muscle tissues indicated that the $\delta^{15} \mathrm{~N}$ values of Berryteuthis magister and walleye pollock were similar. The median $\delta^{15} \mathrm{~N}$ value of summer 2004 B. magister samples was $11.96 \%(\mathrm{n}=50)$. When grouped by size, the median $\delta^{15} \mathrm{~N}$ values of juvenile $(<120 \mathrm{~mm}, \mathrm{n}=11)$ and adult $(\geq 120 \mathrm{~mm}, \mathrm{n}=39)$ squid were 10.90 and $12.19 \%$, respectively. The median $\delta^{15} \mathrm{~N}$ values of juvenile and adult pollock captured in summer 2005 were $11.66 \%$ o $(n=10)$ and $12.03 \%$ o $(n=10)$, respectively (Fig. 6). The $\delta^{15} \mathrm{~N}$ values of the remaining fishes collected in summer 2005 were substantially greater than B. magister, ranging between 14.16 and $16.09 \%$ (Fig. 6).

\section{Isotope analysis of squid eye lenses}

The number of individual lens segments analyzed per squid eye (proximal lens) varied between 6 and 11, and the average width of these lens segments was 0.79 $\pm 0.41 \mathrm{~mm}$. To approximate the mantle lengths of Berryteuthis magister at the time the segments were laid down, we developed squid proximal eye lens width to squid mantle length regressions. We applied linear regression to summer 2004 B. magister data and found a strong, positive relationship $\left(\mathrm{R}^{2}=0.94, a=\right.$ 0.026, $b=1.075, \mathrm{df}=46, F=757.7, \mathrm{p}<0.001$ ) between squid eye lens width and body size. The winter 2007 samples did not exhibit a linear relationship, thus we fit the data using a non-linear Gompertz function $\left(\right.$ Asym $=8.380, \mathrm{p}<0.001 ; b_{2}=11.342, \mathrm{p}=0.117 ; b_{3}=$ 0.977, $\mathrm{p}<0.001)$. The Gompertz function was not chosen based on any presumed mechanistic basis to relate eye lens to body size, but rather because it is a flexible function that could fit the observed relationship. The relationship between squid eye lens width and body size differed between seasons. The widths of the summer lenses continued to increase over increasing body sizes, while the widths of the winter eye lenses appeared to have leveled off at squid mantle lengths of $>200 \mathrm{~mm}$.

The eye lens segments revealed variations in the trophic relations of squid at fine temporal scales. We estimated that, on average, the individual eye lens segments represented approximately a $16 \pm 2.0 \mathrm{~d}$ period. Back calculations based on this estimate indicated that the $\delta^{15} \mathrm{~N}$ and $\delta^{13} \mathrm{C}$ signatures of winter 2007 squid lenses reflected prey consumed by squid over lifetimes that spanned early to mid-autumn through early to midwinter (Fig. 7a,b). In a similar manner, we found that the $\delta^{15} \mathrm{~N}$ and $\delta^{13} \mathrm{C}$ signatures of summer 2004 squid eye lenses reflected prey consumed by Berryteuthis magister from early winter through early to mid-summer (Fig. 7a,b). From the reconstructed trophic records we were able to detect increases and declines in $\delta^{15} \mathrm{~N}$ and $\delta^{13} \mathrm{C}$ of individual $B$. magister at short time intervals over their entire life span.

The $\delta^{15} \mathrm{~N}$ and $\delta^{13} \mathrm{C}$ signatures of the squid eye lenses also revealed that the trophic record of Berryteuthis magister varied in notable ways among individuals (Fig. 7a,b). We classified the squid $\delta^{15} \mathrm{~N}$ trophic records as 2 trends: (1) a 'conventional' monotonic increase in $\delta^{15} \mathrm{~N}$ with increasing body size or (2) a non-monotonic trend with body size (i.e. an initial increase in $\delta^{15} \mathrm{~N}$ fol- 
Table 2. Berryteuthis magister. Capture depths and body sizes analyzed for seasonal $\delta^{15} \mathrm{~N}$ and $\delta^{13} \mathrm{C}$ signatures of mantle muscle tissue ( $\mathrm{n}=$ sample size). Student's $t$-tests were performed to identify potential seasonal differences between capture depths, squid body sizes, $\delta^{15} \mathrm{~N}$ and $\delta^{13} \mathrm{C}$ signatures, and C:N ratios. The Spearman correlation test was used to identify significant correlations between $B$. magister isotope signatures and latitude and capture depth

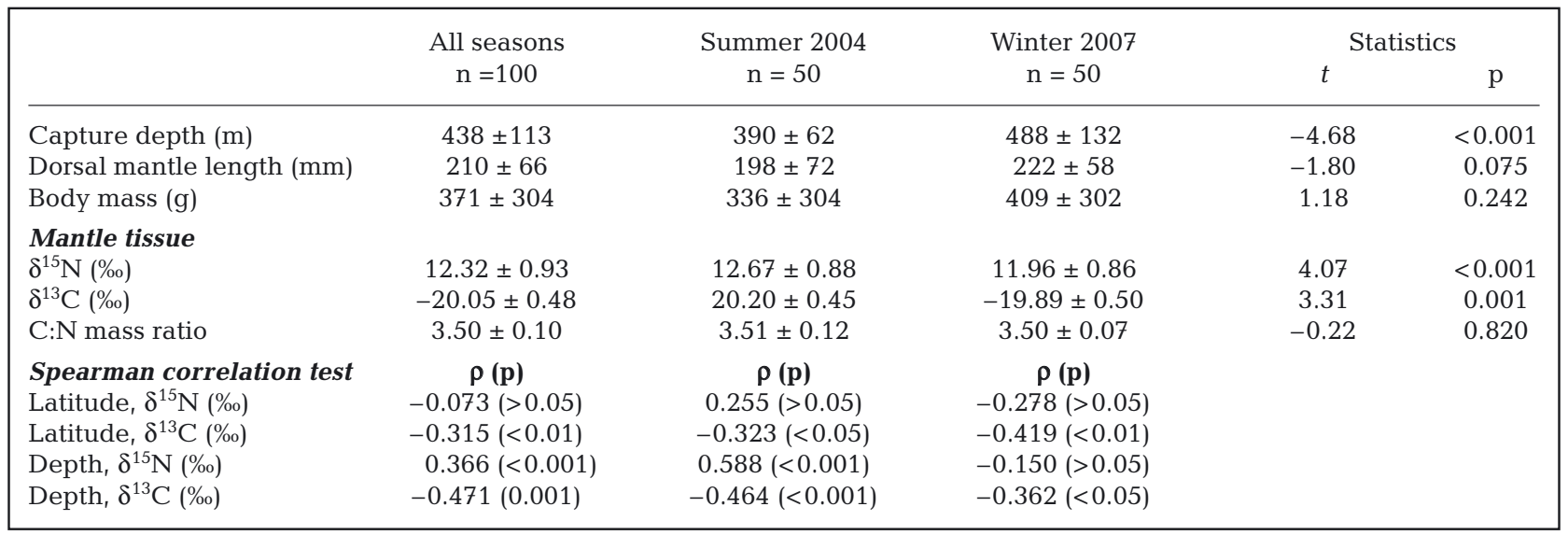

lowed by a decrease or vice versa). Based on estimated slope values, we found that $45 \%$ of the total squid samples demonstrated a significant, positive slope $(\mathrm{p}<$ 0.10) or a 'conventional' pattern. When we quantified the occurrence of significant, positive slope for each sampling season, we found that the variability in feeding chronologies may be season dependent: $70 \%$ of the winter samples exhibited the 'conventional' pattern, whereas only $20 \%$ of the summer samples demonstrated a significant linear increase in $\delta^{15} \mathrm{~N}$. We also found seasonal differences in the variation of $\delta^{15} \mathrm{~N}$ as a function of mantle length (e.g. $~ 3 \%$ for Novem-

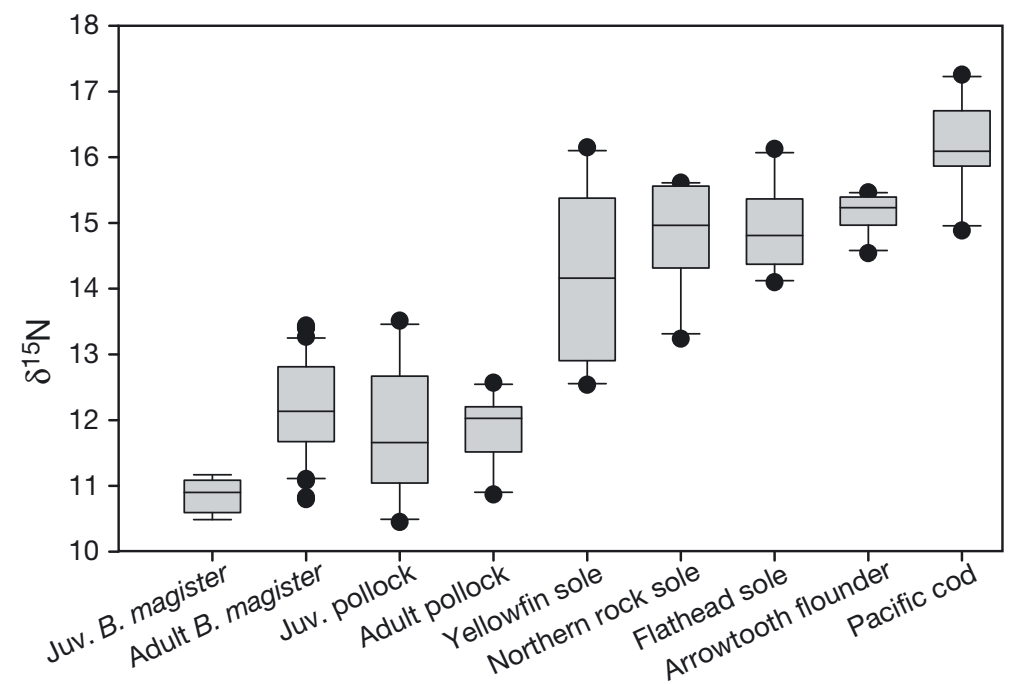

Fig. 6. $\delta^{15} \mathrm{~N}$ signatures of Berryteuthis magister and commercial fishes (C. Kurle, E. Sinclair, A. Edwards, C. Gudmundson unpubl. data) captured in the eastern Bering Sea during summer 2004 and summer 2005, respectively. The isotopic signatures were quantified from squid and fish muscle tissue. The box boundaries indicate the 25 th and 75 th percentiles. Whiskers below and above the box indicate the 10th and 90th percentiles ber 2006 and $\sim 5$ to $6 \%$ for July 2004; Fig. 7a) as well as within season sub-groupings (e.g. early July 2004; Fig. 7a).

Overall, the slope relating eye lens $\delta^{15} \mathrm{~N}$ to body size was positive $(t=4.12$, df $=305, \mathrm{p}<0.001)$. The degree to which lens $\delta^{15} \mathrm{~N}$ values increased with mantle length differed between summer 2004 and winter 2007 samples $(t=3.14$, df $=304, \mathrm{p}=0.002)$. The average lens $\delta^{15} \mathrm{~N}$ value did not significantly differ between the 2 periods $(t=0.58, \mathrm{df}=37, \mathrm{p}=0.560)$. The slope of lens $\delta^{13} \mathrm{C}$ values across all individuals was not significantly different from $0(t=0.57 \mathrm{df}=305, \mathrm{p}=0.573)$; however, the slope and intercept of lens $\delta^{13} \mathrm{C}$ values differed between summer 2004 and winter 2007 samples $(t=4.60 \mathrm{df}=304, \mathrm{p}=0.000$ and $t=7.01$, $\mathrm{df}=37, \mathrm{p}=0.000)$. Lastly, the average slope of eye lens $\delta^{15} \mathrm{~N}$ values was lower than the slope of $\delta^{15} \mathrm{~N}$ values estimated from muscle tissue analysis (0.004 and 0.009 , respectively). The slopes of winter eye lens $\delta^{15} \mathrm{~N}$ values were similar to winter muscle tissue signatures (0.007 and 0.009), but the average slope of summer eye lens $\delta^{15} \mathrm{~N}$ values was lower than the slope of summer muscle tissue signatures $(0.001$ and 0.010$)$. The slopes of eye lens and muscle tissue $\delta^{13} \mathrm{C}$ values showed opposite trends in both winter $(-0.004$ and 0.004) and summer (0.004 and-0.003) squid samples.

\section{DISCUSSION}

Our study on the trophic role of Berryteuthis magister in the EBS continental slope ecosystem produced 3 main findings. First, stomach content and stable isotope analyses revealed that $B$. 
magister exhibits an overall increase in trophic position with ontogeny. The incidence of fish and squid prey in $B$. magister stomach contents gradually increased with increasing squid mantle length, and the muscle $\delta^{15} \mathrm{~N}$ signatures revealed that the food web position of $B$. magister increased by approximately 1 trophic level between juvenile and adult life stages. Second, B. magister did not exhibit size-dependent patterns of piscivory. The body sizes of fish prey consumed by B. magister remained constant with increasing predator mantle length. Third, in our attempt to reconstruct the feeding chronologies of individual B. magister, we found substantial variability in squid trophic records. The feeding chronologies did not consistently reflect a monotonic increase in squid trophic position; nonmonotonic patterns were relatively common. Our results also indicate that the variability in feeding chronologies may be season dependent. These findings suggest that there may be finer-scale spatiotemporal variations in squid trophic records, possibly related to seasonal prey availability, that are not captured by traditional isotope analyses of squid muscle tissue.
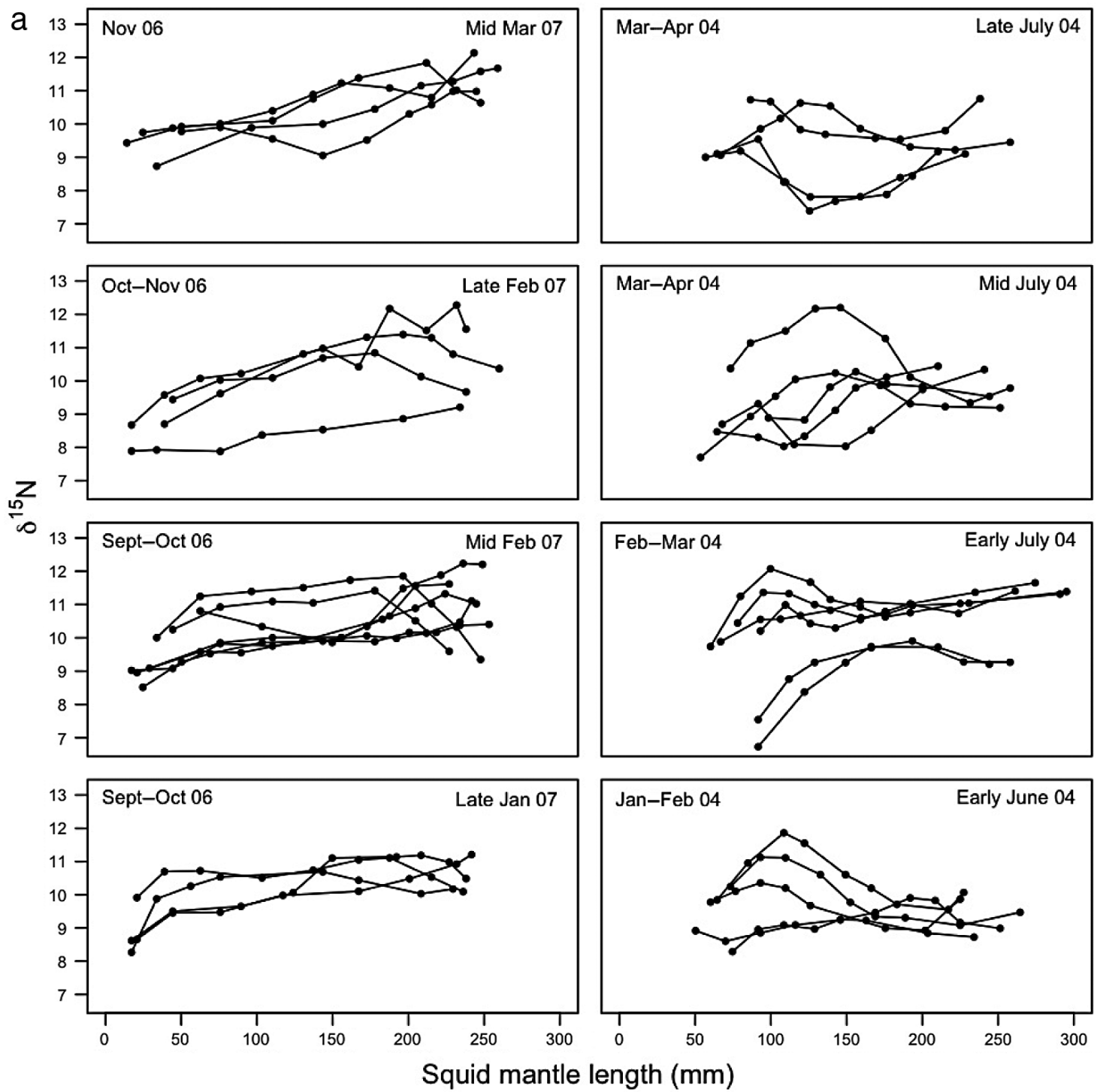

Fig. 7. Berryteuthis magister. Reconstructed feeding chronologies of individual squid captured in summer 2004 (right-hand columns) and winter 2007 (left-hand columns). The lines reflect the relationship between the (a) $\delta^{15} \mathrm{~N}$ signatures and (b, next page) $\delta^{13} \mathrm{C}$ signatures of $B$. magister eye lens segments and the estimated mantle lengths of squid when the segments were deposited. Each line represents an individual squid. The squid are grouped by capture date (month and year; upper right-hand corner of box) and approximate time at which the first lens segment was laid down (month and year; upper left-hand corner of box). The regression equations are $y=9.50+0.001 x, y=9.28+0.007 x$, and $y=9.38+0.004 x$ for summer, winter, and all squid eye lens $\delta^{15} \mathrm{~N}$ values versus mantle length, respectively. The regression equations are $y=-20.36-0.004 x, y=-18.31-0.005 x$, and $y=-19.31-0.001 x$ for summer, winter, and all squid eye lens ${ }^{13} \mathrm{C}$ values versus mantle length, respectively 
b
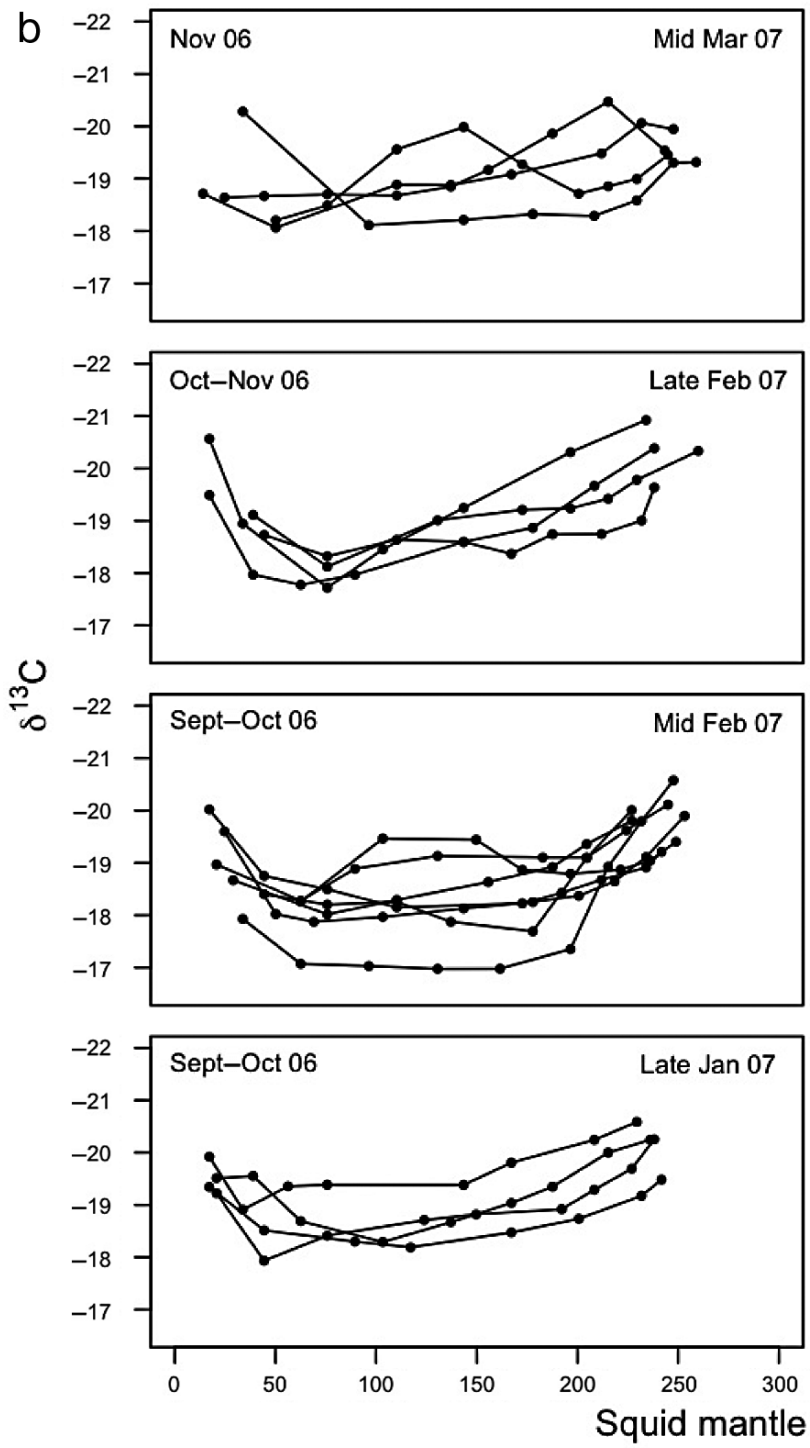
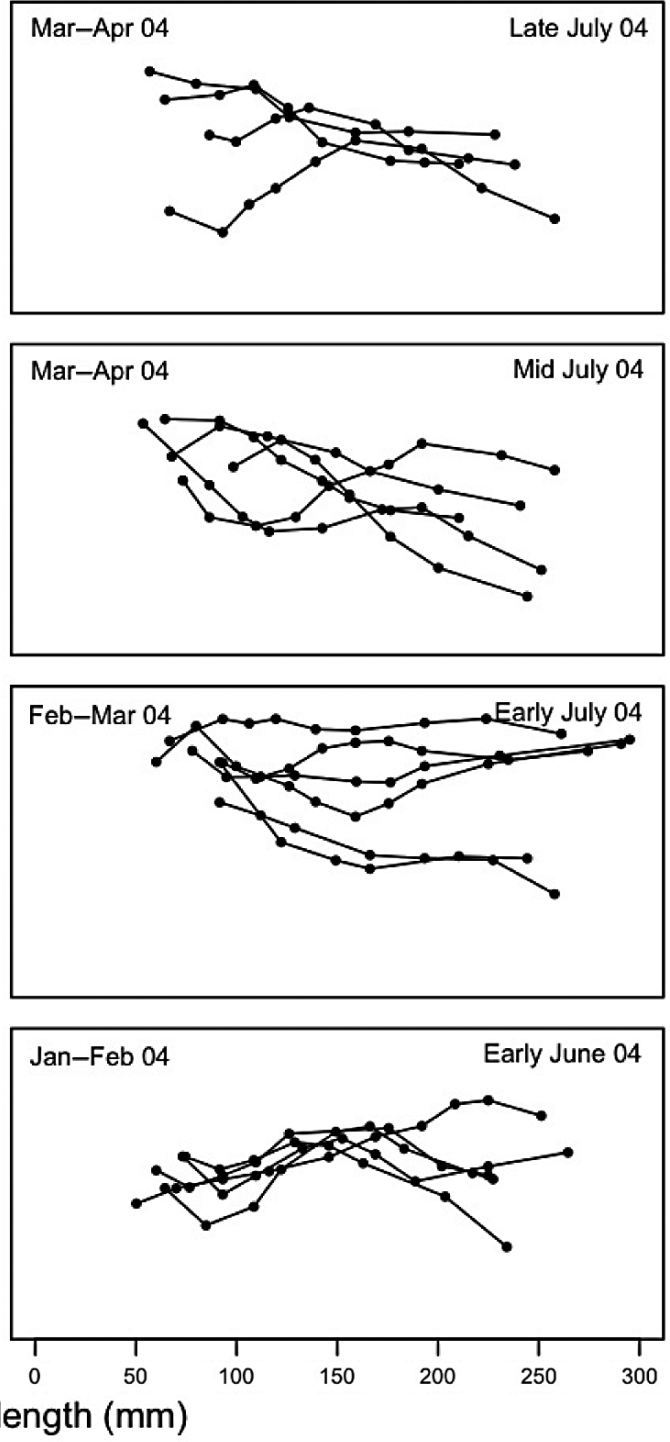

Fig. 7 (continued)

\section{General diet analysis}

The stomach content analyses indicate that Berryteuthis magister does not demonstrate feeding habits typified by squid species that are potentially important predators of higher trophic level fishes. For example, in the northwest Atlantic Ocean, the longfin inshore squid Loligo pealeii exhibits a rapid onset of piscivory, preys on the juvenile stages of its predators, including commercially valuable species, and demonstrates sizerelated patterns of piscivory (Hunsicker \& Essington 2006). L. pealeii and other squid species exhibiting similar feeding traits have been described as voracious predators that may constrain the recruitment success of commercially targeted fishes (Rodhouse \& Nigmatullin 1996, Dawe et al. 1997, Hunsicker \& Essington 2006, 2008, Field et al. 2007). However, the diet con- tents of B. magister revealed a slower ontogenetic shift to piscivory, and this species preyed mostly upon deepwater forage fishes and showed little evidence of sizerelated feeding constraints. These findings suggest that B. magister may interact with higher trophic level fishes through indirect food web pathways (i.e. sharing or competing for prey resources) rather than directly as a predator. The discrepancy in the types of fish prey consumed by $B$. magister and other well-studied squid may be explained by the differences in their migratory behaviors. Many squid species, including L. pealeii, undergo seasonal onshore and offshore migrations (Serchuk \& Rathjen 1974, Ogawa et al.1983, Hatfield \& Rodhouse 1991, 1994, Augustyn et al. 1993, Roberts \& Sauer 1994). As a result, they likely experience high spatiotemporal overlap with the early life stages of high trophic level fishes at spawning and/or nursery 
grounds. In contrast, $B$. magister inhabit the edge of the continental shelf and slope over most of their lifetime and do not undergo shelf migrations (Kubodera et al. 1983, Nesis 1985, Okutani et al. 1988). Thus, $B$. magister probably encounter a higher abundance of deepwater slope fishes (i.e. myctophids) than the juvenile stages of many commercially harvested fish species that inhabit shelf waters.

\section{Prey size spectrum}

The lack of evidence for size-related constraints on piscivory by Berryteuthis magister could be due to prey availability. Previous studies of squid feeding ecology have shown that squid predation is dictated by predator and prey body sizes (Rocha et al. 1994, Collins \& Pierce 1996, Phillips et al. 2003, Hunsicker \& Essington 2006). Prey body sizes typically increase with increasing squid mantle length because squid feeding becomes less constrained by morphological limitations as squid grow. However, our results show that body size constraints may not be an important agent dictating the frequency of piscivory by B. magister. We observed an increase in the occurrence of fish in $B$. magister stomach contents over ontogeny, but the sizes of fish consumed by $B$. magister were independent of squid mantle length. A potential explanation is that $B$. magister encountered a limited size range of fish prey in their habitat, and thus our analysis reflects prey availability rather than size constraints. We expect quantile regression to be an effective technique for identifying size constraints when squid are feeding opportunistically on prey items of any size. However, in this study a large majority of the fishes consumed by $B$. magister were northern smooth-tongue Leuroglossus schmidti, suggesting that $B$. magister mainly encountered schools of this fish species. Size-related constraints may have been more evident if we had prey size estimates for a wider size range of $B$. magister. Identifiable otoliths were only found in the stomachs of squid with large body sizes.

\section{Stable isotope analyses}

Stable isotope analysis of squid muscle tissue has been used successfully as a tool for investigating the role of squid as predator and prey (Hobson et al. 1994, Takai et al. 2000, Cherel \& Hobson 2005, Ruiz-Cooley et al. 2006, Stowasser et al. 2006, Parry 2008, Cherel et al. 2009). Our results are consistent with many of these studies. For example, the ontogenetic increase in $\delta^{15} \mathrm{~N}$ observed from Berryteuthis magister muscle tissue has been found for many squid species (Ruiz-Cooley et al.
2004, Parry 2008, Cherel et al. 2009). Similar to B. magister, the food web position of 3 oceanic squids increases by at least 1 trophic level with ontogeny: the $\delta^{15} \mathrm{~N}$ values of Todarodes filippovae, Dosidicus gigas, and Ommastrephes bartramii muscle tissues were shown to increase by $\sim 3, \sim 4$, and $>5 \%$, respectively (Parry 2008, Cherel et al. 2009, see Ruiz-Cooley et al. 2010). Also, consistent with a recent study (Cherel et al. 2009), we found little variation in the $\delta^{13} \mathrm{C}$ signatures of squid muscle tissue with increasing mantle length. This was expected because the enrichment of carbon isotopes per trophic level is low (i.e. $\sim 1 \%$; DeNiro \& Epstein 1978, Tieszen et al. 1983) compared to nitrogen isotopes (i.e. 3 to $4 \%$; Minagawa \& Wada 1984). Further, similar to Takai et al. (2000), we found a significant negative correlation between the $\delta^{13} \mathrm{C}$ signatures of $B$. magister muscle tissue and intra-specific capture location, but did not find a significant correlation between $\delta^{15} \mathrm{~N}$ and latitude. The $\delta^{13} \mathrm{C}$ signatures likely reflect the latitudinal characteristics of phytoplankton carbon isotopes, whereas the large enrichment in $\delta^{15} \mathrm{~N}$ per trophic level may have weakened any correlation between squid $\delta^{15} \mathrm{~N}$ values and latitudinal variation in phytoplankton $\delta^{15} \mathrm{~N}$ signatures (Takai et al. 2000). We note that our findings on squid carbon isotopes need to be interpreted with caution, particularly when making comparisons between species or taxa, because lipids $\left({ }^{13} \mathrm{C}\right.$-depleted) were not extracted from $B$. magister muscle tissues prior to analysis.

One unexpected finding in our study was the correlation between squid isotope signatures and capture depth. It is possible that the capture location (i.e. latitudinal effect) confounds the negative relationship between $\delta^{13} \mathrm{C}$ and depth while the positive relationship between $\delta^{15} \mathrm{~N}$ and capture depth is related to squid body size. For instance, the adult stages of Berryteuthis magister are known to inhabit deeper depths than the juveniles (Nesis 1997, 1998, Arkhipkin et al. 1998), and thus we may expect to observe higher $\delta^{15} \mathrm{~N}$ signatures with increasing depths. The positive correlation between $\delta^{15} \mathrm{~N}$ and capture depth could also be attributed to differences in the $\delta^{15} \mathrm{~N}$ values of deep- and surfacewater prey items. Several authors have found that the $\delta^{15} \mathrm{~N}$ values of marine predators feeding on mesopelagic prey resources are higher than the $\delta^{15} \mathrm{~N}$ of predators feeding on epipelagic prey (Graham et al. 2007, Ménard et al. 2007, Lorrain et al. 2009). Graham et al. (2007) hypothesized that this trend reflects the higher $\delta^{15} \mathrm{~N}$ values of deep-water prey species, which is an effect of nutrient cycling. The nitrogen isotopes and stomach contents of $B$. magister indicate that squid consumed mostly deep-water prey in the winter period, whereas epipelagic and mesopelagic prey were of similar importance in squid diets during the summer. The summer samples (year 2004) exhibited a 
positive correlation between $\delta^{15} \mathrm{~N}$ values and capture depth, and no correlation was found for winter samples. Also, fish dominated the diets of winter squid over all capture depths, while the occurrence of fish and squid in summer squid diets was similar across depths. Together, these findings suggest that the summer squid fed across a strong $\delta^{15} \mathrm{~N}$ depth gradient, whereas the winter squid fed more consistently on mesopelagic fishes (e.g. northern smooth-tongue) with similar $\delta^{15} \mathrm{~N}$ signatures. Standardized sampling of $B$. magister and prey isotope signatures is needed to better examine the influences of body size, capture depth, and latitude on squid $\delta^{15} \mathrm{~N}$ and $\delta^{13} \mathrm{C}$ values. Analyses of squid and prey isotope signatures from multiple years and seasons are also needed to determine if our findings are indicative of a season or year effect. Interpretations of our findings are limited by the opportunistic manner in which $B$. magister samples were collected (i.e. different years, depths, and latitudes).

Comparisons of $\delta^{15} \mathrm{~N}$ values from squid and fish muscle tissues revealed that Berryteuthis magister might occupy a trophic position similar to or lower than several commercial fishes inhabiting the shelf and slope regions. Specifically, the isotope signatures indicate that adult B. magister could occupy a similar trophic level as adult and juvenile walleye pollock ( $>100 \mathrm{~mm}$ and $\leq 100 \mathrm{~mm}$, respectively). The $\delta^{15} \mathrm{~N}$ values of these 2 species are not directly comparable because the squid and fish samples were collected at different locations in the EBS and during consecutive years (2004 and 2005, respectively). Our interpretation of these results is limited because we cannot show fish capture locations due to the NOAA Fisheries Observer Program confidentiality statutes. However, diet analyses also show that B. magister and pollock consume similar prey items, such as northern smooth-tongue, lampfish, and lanternfish (Lang et al. 2005). Further, B. magister and walleye pollock are known to overlap spatially and temporally in the EBS (www.afsc.noaa.gov/FMA). These findings suggest that these species share prey resources and that there could be potential for competition if resources became limited. Quantifying the extent of the dietary overlap of $B$. magister and walleye pollock should be a focus of future work.

\section{Isotope analysis of squid eye lenses}

Stable isotope analyses of the Berryteuthis magister eye lenses provide a richer picture of squid trophic ontogeny. Our results indicate that squid diets may not simply increase from lower to higher trophic level prey items with increasing body size, but that there can be substantial and sustained deviations over time or body size. The slopes of $\delta^{15} \mathrm{~N}$ in squid muscle tissue and eye lenses in relation to squid mantle length suggest higher variation among the $\delta^{15} \mathrm{~N}$ signatures estimated from squid eye lens layers. Also, the individual feeding chronologies revealed finer temporal variations in $\delta^{15} \mathrm{~N}$ and $\delta^{13} \mathrm{C}$ signatures that were not evident from analysis of muscle tissues. Short-term changes in squid $\delta^{15} \mathrm{~N}$ and $\delta^{13} \mathrm{C}$ ratios could be due to changes in individuals' feeding habits, prey availability, or localized differences in prey isotope signatures. Temporal variation in prey $\delta^{15} \mathrm{~N}$ levels can be quite pronounced among short-lived, high turnover species (e.g. zooplankton), but would generally not be revealed in the $\delta^{15} \mathrm{~N}$ tissues of predators if taken from tissues with slower turnover times (Jennings et al. 2008). Indeed, our analysis of muscle tissue suggested a monotonic increase in $\delta^{15} \mathrm{~N}$ values with increasing squid mantle length: the turnover time of squid muscle tissue varies from a few weeks to a few months (Ruiz-Cooley et al. 2006). While we cannot discern whether feeding habits or the underlying prey $\delta^{15} \mathrm{~N}$ and $\delta^{13} \mathrm{C}$ signatures are ultimately responsible for the observed trends in feeding chronologies, our results do point to the presence of intermediate-scale variability in the food webs that support squid.

The variability in Berryteuthis magister trophic records revealed by squid eye lenses is supported by earlier studies. Parry (2003) developed the eye lens method to reconstruct the feeding chronologies of 2 squid species in the north Pacific sub-tropical gyre, Ommastrephes bartramii and Sthenoteuthis oualaniensis. These squid also exhibited individual variability and non-monotonic trends of lens $\delta^{15} \mathrm{~N}$ values as a function of mantle length. However, these species also demonstrated greater shifts in lens $\delta^{15} \mathrm{~N}$ values over their lifetimes than B. magister. For instance, the $\delta^{15} \mathrm{~N}$ values for individual $S$. oualaniensis and $O$. bartramii varied by as much $6.67 \%$ (mean $4.25 \pm 1.91 \%$ ) and $13 \%$ (mean $8.85 \pm 3.27 \%$ ) across mantle lengths, respectively. The maximum range of $\delta^{15} \mathrm{~N}$ across $B$. magister across body size was 3.6\% (mean $2.08 \pm$ $0.63 \%$ ). These differences among species could reflect differences in their trophic ecology and/or migration patterns. For example, $O$. bartramii exhibit large, seasonal migrations between spawning and feeding grounds (Murata \& Nakamura 1998), whereas S. oualaniensis and $B$. magister do not undergo any known seasonal migrations. As a result, $O$. bartramii are likely to encounter greater latitudinal shifts in isotope signatures over their lifetime and assimilate a wider range of $\delta^{15} \mathrm{~N}$ in their tissues (Parry 2003).

The work of Ruiz-Cooley et al. (2010) further corroborates our findings of Berryteuthis magister trophic records. These authors reconstructed the feeding chronologies of individual Humboldt squid Doscidicus gigas using the $\delta^{15} \mathrm{~N}$ signatures of proostracum sec- 
tions sub-sampled from squid gladii. Consistent with the $B$. magister eye lenses, the $\delta^{15} \mathrm{~N}$ and $\delta^{13} \mathrm{C}$ signatures of $D$. gigas gladii were highly variable over squid body size, and there was an overall increase in the $\delta^{15} \mathrm{~N}$ values of sampled sections as squid became larger. The squid gladii exhibited greater differences in the mean isotope values of young and old segments than the $B$. magister eye lenses. For example, based on estimated regression models, the mean $\delta^{15} \mathrm{~N}$ and $\delta^{13} \mathrm{C}$ values of squid gladii differed by 1.6 and $0.6 \%$, respectively, between new $(6 \mathrm{~cm})$ and old sections $(40 \mathrm{~cm})$, whereas the mean isotope differences of $B$. magister lens layers laid down at juvenile $(6 \mathrm{~cm})$ and adult $(30 \mathrm{~cm})$ stages differed by $0.96 \%$ for $\delta^{15} \mathrm{~N}$ and $0.24 \%$ for $\delta^{13} \mathrm{C}$. Again, this finding could be an effect of differences in trophic ecology and/or lifetime migration patterns. In contrast to $B$. magister, D. gigas are large, voracious predators and are highly mobile (Nigmatullin et al. 2001). This finding could also reflect the differences in the molecular structure and isotope fractionation rates of squid eye lenses and gladii. Our results and those of Parry (2003) show that $\delta^{15} \mathrm{~N}$ signatures of squid eye lenses are often lower than the $\delta^{15} \mathrm{~N}$ of squid muscle tissue. The ontogenetic shift in isotope values measured from squid eye lenses was also lower than those measured from squid muscle tissue (Parry 2003, present study). Similarly, the findings of Cherel et al. (2009) and Ruiz-Cooley et al. $(2006,2010)$ indicate that the isotopic signatures of squid hard parts (beaks and gladii) had lower $\delta^{15} \mathrm{~N}$ signatures and demonstrated smaller ontogenetic shifts in isotope values than soft tissue. These authors suggest that the differences are due to the presence of chitin in squid hard parts, which is a ${ }^{15} \mathrm{~N}$-depleted molecule. A comprehensive study that examines how squid isotope signatures vary among eye lenses, beaks, gladii, and muscle tissue is needed to make better comparisons between squid isotope studies.

The reconstructed feeding chronologies of Berryteuthis magister might reflect a shift in seasonal foraging strategies. The variation among individual trophic records was higher among squid caught in summer than those captured in winter. Also, the winter squid more often exhibited conventional trophic patterns; squid trophic level increased with increasing body size. These differences might be attributed to the seasonal availability of prey to $B$. magister over their short lifetime. For instance, the maximum age (post-embryonic growth) of squid captured in the EBS was estimated to be $\sim 180 \mathrm{~d}$ (Drobny 2008). Thus, it is possible that $B$. magister collected in the EBS during summer months were exposed to highly productive ocean conditions (spring and summer) over much of their life span. The high abundance of different prey types available to the summer-caught squid would have allowed them to feed opportunistically, potentially resulting in more variation among the trophic history of individual squid. In contrast, B. magister caught during the winter months were likely to encounter less productive conditions (autumn and winter) and would have been more limited by prey choice. Under such conditions, squid may need to search for additional food items in deeper waters where prey $\delta^{15} \mathrm{~N}$ values may be inherently higher. They might also shift toward more specialized feeding strategies when prey abundance is low to reduce intra-specific competition and maximize energetic return. Previous authors have documented similar shifts in the seasonal foraging patterns of demersal fishes (Reum \& Essington 2008), and others have suggested that spatial or temporal variation in prey availability and the phenotypic differences among individuals that influence foraging success could promote the divergence of a generalist population into alternate foraging specialists (Partridge \& Green 1985, Magurran 1986, Estes et al. 2003). It is plausible that squid also shift their foraging strategy in response to changes in seasonal and/or annual prey availability. This notion is supported by the findings Ruiz-Cooley et al. (2010), which suggest that the variable but increasing $\delta^{15} \mathrm{~N}$ and $\delta^{13} \mathrm{C}$ along the proostracum of Doscidicus gigas gladii is an effect of prey availability and optimal foraging strategy. Feeding chronologies of squid captured in multiple seasons and years are needed to evaluate if the $B$. magister trophic records reflect seasonal environmental conditions or are instead an effect of sampling year (e.g. 2004 versus 2007).

Our study demonstrates that squid eye lenses can provide a chronology of trophic position over time. We chose to analyze squid eye lenses because the tissue layers are readily distinguishable over the entire lens structure, and the numerous segments of the lens tissue laid down over a squid's lifetime can be sampled with ease. Feeding chronologies reconstructed from squid eye lenses and gladii are a valuable tool, as they could improve our ability to evaluate the trophic ecology of squid life stages or species that are difficult to capture with traditional sampling gear. For example, adult Berryteuthis magister are frequently captured in bottom trawl surveys or as by-catch in commercial fisheries, but the juvenile stages of $B$. magister are more widely dispersed in pelagic habitats (Arkhipkin et al. 1998, Nesis 1998) and are not often captured by traditional sampling methods. To be able to apply the eye lens method in a more rigorous fashion, direct experimental work is needed to validate the assumptions we made here. Also, future work should attempt to verify how often layers of eye lenses are laid down and to relate the age of squid to the time when the tissues were formed. This information can be used to develop more precise estimates of the time scales over which 
prey isotope signatures are measured and to determine whether there is any synchrony among the age of individuals and their trophic signatures. We could not use squid growth models to back-calculate the age of squid to the time when the tissues were formed due to the high variability surrounding the estimated ages of B. magister inhabiting the EBS (Drobny 2008). However, we did use these estimates to generate coarse approximations of the time at which the first eye lens segments were laid down. We emphasize that these results need to be interpreted with caution because there is some discrepancy between the estimates used in our study and those from an earlier study. Arkhipkin et al. (1996) aged B. magister from the western Bering Sea and found that they live longer than $1 \mathrm{yr}$.

In summary, our study used 3 complementary methods to provide valuable information on the trophic position of Berryteuthis magister in the EBS and to reveal the individual variation in trophic ontogeny that is masked by traditional stomach content and stable isotope analyses. Future work should aim to concurrently sample and identify the isotope signatures of $B$. magister and their prey over multiple seasons and years. This would allow one to better evaluate the seemingly important effects of body size, depth, latitude and season on squid trophic ecology. Such work would build on the present study and further improve our knowledge of the role of B. magister in the EBS food web and their potential to impact juvenile fishes through indirect food web pathways. Better knowledge of $B$. magister trophic interactions is important for broadening our understanding of how human and environmental forcing can affect the EBS ecosystem.

Acknowledgements. We thank C. Anderson, T. Buckley, J. Hoff, S. Parker-Stetter, A. Whitehouse, and North Pacific Groundfish Observer Monitoring Program personnel for collecting samples for this project. We thank W. Walker and J. Thomason at the National Marine Mammal Laboratory for their help in the identification of squid beaks and fish otoliths; and D. Beauchamp for his helpful comments on the manuscript. We also thank 3 anonymous reviewers for their thoughtful comments and suggestions for improving this paper. This project was funded by the North Pacific Research Board and NOAA Fisheries-Alaska Fisheries Science Center.

\section{LITERATURE CITED}

Alexander V (1999) Interdisciplinary studies of the Bering Sea. In: Loughlin TR, Ohtani K (eds) Dynamics of the Bering Sea. AK- SG-99-03. University of Alaska Sea Grant Press, Fairbanks, AK, p 683-776

Arkhipkin AI, Bizikov VA, Krylov VV, Nesis KN (1996) Distribution, stock structure, and growth of the squid Berryteuthis magister (Berry, 1913) (Cephalopoda, Gonatidae) during summer and fall in the western Bering Sea. Fish Bull 94:1-30

Arkhipkin AI, Bizikov VA, Verkhunov VA (1998) Distribution and growth in juveniles of the squid Berryteuthis magister (Cephalopoda, Gonatidae) in the western Bering Sea. Sarsia 83:45-54

Augustyn CJ, Roel BA, Cochrane KL (1993) Stock assessment in the chokka squid Loligo vulgaris reynaudii fishery off the coast of South Africa. In: Okutani T, O'Dor RK, Kubodera $\mathrm{T}$ (eds) Recent advances in cephalopod fisheries biology. Tokai University Press, Tokyo, p 3-14

Aydin K, Gaichas S, Ortiz I, Kinzey D, Friday N (2007) A comparison of the Bering Sea, Gulf of Alaska, and Aleutian Islands large marine ecosystems through food web modeling. US Dept Commer, NOAA Tech Memo NMFS-AFSC178

Cherel Y, Hobson KA (2005) Stable isotopes, beaks and predators: a new tool to study the trophic ecology of cephalopods, including giant and colossal squids. Proc Biol Sci 272:1601-1607

> Cherel Y, Fontaine C, Jackson JD, Jackson CH, Richard P (2009) Tissue, ontogenetic and sex-related differences in $\delta^{13} \mathrm{C}$ and $\delta^{15} \mathrm{~N}$ values of the oceanic squid Todarodes filippovae (Cephalopoda: Ommastrephidae). Mar Biol 156: 699-708

Clarke MR (1996) The role of cephalopods in the world's oceans: general conclusions and the future. Philos Trans R Soc Lond B Biol Sci 351:1105-1112

Collins MA, Pierce GJ (1996) Size selectivity in the diet of Loligo forbesi (Cephalopoda: Loliginidae). J Mar Biol Assoc UK 76:1081-1090

Croxall JP, Prince PA (1996) Cephalopods as prey. I. Seabirds. Philos Trans R Soc Lond B Biol Sci 351:1023-1043

Dawe EG (1988) Length-weight relationships for shortfinned squid in Newfoundland and the effect of diet on condition and growth. Trans Am Fish Soc 117:591-599

Dawe EG, Dallet EL, Lidster WW (1997) Fish prey spectrum of short-finned squid (Illex illecebrosus) at Newfoundland. Can J Fish Aquat Sci 54(Suppl 1):200-208

DeNiro MJ, Epstein S (1978) Influence of diet on the distribution of carbon isotopes in animals. Geochim Cosmochim Acta 42:495-506

> Dove SG (1999) Ontological changes in the crystallin composition of the eye lenses of the territorial damselfish Parma microlepis and their possible effects on trace-metal accumulation. Mar Biol 134:653-663

Drobny SP (2008) Life history characteristics of the gonatid squid Berryteuthis magister in the eastern Bering Sea. MS thesis, University of Alaska, Fairbanks, AK

Estes JA, Reidman ML, Staedler LM, Tinker MT, Lyon BE (2003) Individual variation in prey selection by sea otters: patterns, causes, and implications. J Anim Ecol 72: $144-155$

Field JC, Baltz K, Phillips A, Walker WA (2007) Range expansion and trophic interactions of the jumbo squid, Doscidicus gigas, in the California Current. Calif Coop Ocean Fish Invest Rep 48:131-146

Frost KJ, Lowry LF (1981) Food and trophic relationships of cetaceans in the Bering Sea. In: Wood DW, Calder JA (eds) The eastern Bering Sea shelf: oceanography and resource, Vol 2. University of Washington Press, Seattle, WA, p 825-836

Gorbatenko KM, Chuchukalo VI, Shevtsov GA (1995). Daily ration of two abundant species of squids in the Bering and Okhotsk Seas in autumn-winter time. In: Kotenev BN, Sapozhnikov VV (eds) Complex studies of the Bering Sea ecosystem. VNIRO, Moscow, p 349-357

Graham BS, Grubbs D, Holland K, Popp BN (2007) A rapid ontogenetic shift in the diet of juvenile yellowfin tuna from Hawaii. Mar Biol 150:647-658 
Gudmundson CJ, Zeppelin TK, Ream RR (2006) Application of two methods for determining diet in northern fur seals (Callorhinus ursinus). Fish Bull 104:445-455

Hatfield EMC, Rodhouse PG (1991) Biology and fishery of the Patagonian squid Loligo gahi (d'Orbigny, 1835): a review of current knowledge. J Ceph Biol 2:41-79

Hatfield EMC, Rodhouse PG (1994) Migration as a source of bias in the measurement of cephalopod growth. Antarct Sci 6:179-184

Hobson KA, Piatt JF, Pitocchelli J (1994) Using stable isotopes to determine seabird trophic relationships. J Anim Ecol 63:786-798

Horwitz J (1992) $\alpha$-Crystallin can function as a molecular chaperone. Proc Natl Acad Sci USA 89:10449-10453

Hunsicker ME, Essington TE (2006) Size-structured patterns of piscivory of the longfin inshore squid (Loligo pealeii) in the mid-Atlantic continental shelf ecosystem. Can J Fish Aquat Sci 63:754-765

Hunsicker ME, Essington TE (2008) Evaluating the potential for trophodynamic control of fish by the longfin inshore squid (Loligo pealeii) in the Northwest Atlantic Ocean. Can J Fish Aquat Sci 65:2524-2535

> Jennings S, Pinnegar JK, Polunin NVC, Boon TW (2001) Weak cross-species relationships between body size and trophic level belie powerful size-based trophic structuring in fish communities. J Anim Ecol 70:934-944

Jennings S, Maxwell TAD, Schratzberger M, Milligan SP (2008) Body-size dependent temporal variations in nitrogen stable isotope ratios in food webs. Mar Ecol Prog Ser 370:199-206

> Juanes F (2003) The allometry of cannibalism in piscivorous fishes. Can J Fish Aquat Sci 60:594-602

Karpov KA, Cailliet GM (1978) Feeding dynamics of Loligo opalescens. Calif Dep Fish Game Fish Bull 169:45-65

Kiljunen M, Grey J, Sinisalo T, Harrod C, Immonen H, Jones RI (2006) A revised model for lipid-normalizing $\delta^{13} \mathrm{C}$ values from aquatic organisms, with implications for isotope mixing models. J Appl Ecol 43:1213-1222

Klages NTW (1996) Cephalopods as prey. II. Seals. Philos Trans R Soc Lond B Biol Sci 351:1045-1052

Kubodera TK, Percy WG, Murakami K, Kobayashi T, Nakata J, Mishima S (1983) Distribution and abundance of squids caught in surface gillnets in the subarctic Pacific, 1977-1981. Mem Fac Fish Hokkaido Univ 30:1-49

Lang GM, Livingston PA, Dodd KA (2005) Groundfish food habits and predation on commercially important prey species in the eastern Bering Sea from 1997-2001. US Dept Commer, NOAA Tech Memo NMFS-AFSC-158

Lordan C, Burnell GM, Cross TM (1998) The diet and ecological importance of Illex condetti and Todaropsis eblanae (Cephalopoda: Ommastrephidae) in Irish waters. In: Payne AIL, Lipinski MR, Clarke MR, Roeleveld MAC (eds) Cephalopod biodiversity: ecology and evolution. S Afr J Mar Sci 20:153-163

> Lorrain A, Graham B, Ménard F, Popp B, Bouillon S, van Breugel P, Cherel Y (2009) Nitrogen and carbon isotope values of individual amino acids: a tool to study foraging ecology of penguins in the Southern Ocean. Mar Ecol Prog Ser 391:293-306

Lowry LF, Frost KJ, Calkins DG, Swartzman GL, Hills S (1982) Feeding habits, food requirements, and status of Bering Sea marine mammals. Nos. 19 and 19A, N Pac Fish Manag Counc, Anchorage, AK

- Lundvall D, Svanbäck R, Persson L, Byström P (1999) Sizedependent predation in piscivores: interactions between predator foraging and prey avoidance abilities. Can J Fish Aquat Sci 56:1285-1292
Magurran AE (1986) Individual differences in fish behavior. In: Pitcher TJ (ed) The behavior of teleost fishes. Croon Helm Press, London, p 338-365

> Ménard F, Lorrain A, Potier M, Marsac F (2007) Isotopic evidence of distinct feeding ecologies and movement patterns in two migratory predators (yellowfin tuna and swordfish) of the western Indian Ocean. Mar Biol 153: $141-152$

Minagawa M, Wada E (1984) Stepwise enrichment of $\delta^{15} \mathrm{~N}$ along food chains: further evidence and the relation between $\delta^{15} \mathrm{~N}$ and animal age. Geochim Cosmochim Acta 50:2143-2146

Murata M, Nakamura Y (1998) Seasonal migration and diel vertical migration of the neon flying squid, Ommastrephes bartramii, in the North Pacific. In: Okutani T (ed) Contributed papers to international symposium on large pelagic squids. Japan Marine Fishery Resources Research Center, Tokyo, p 13-30

Nesis KN (1985) Oceanic cephalopods: distribution, life forms, evolution. Nauka, Moscow

- Nesis KT (1997) Gonatid squids in the subarctic North Pacific: ecology, biogeography, niche diversity and role in the ecosystem. Adv Mar Biol 32:243-324

Nesis KN (1998) The gonatid squid, Berryteuthis magister (Berry, 1913): distribution, biology, ecological connections and fisheries. In: Okutani $\mathrm{T}$ (ed) Contributed papers to international symposium on large pelagic squids. Japan Marine Fishery Resources Research Center, Tokyo, p 233-249

Nicol J (1989) The eyes of fishes. Clarendon Press, Oxford

Nigmatullin C, Nesis K, Arkhipkin A (2001) A review of the biology of the jumbo squid Dosidicus gigas (Cephalopoda: Ommastrephidae). Fish Res 54:9-19

Nixon M (1987) Cephalopod diets. In: Boyle PR (ed) Cephalopod life cycle, Vol II, comparative reviews. Academic Press, London, p 201-219

NRC (National Research Council) (1996) The Bering Sea ecosystem. National Academies Press, Washington, DC

Ogawa Y, Moriwaki S, Yamada H, Okajima Y (1983) Migration patterns of Loligo edulis estimated from a joint tagging programme conducted by four prefectures in the southwestern Japan Sea. Coop Invest 'Shiro-ika', Loligo edulis inhabiting western Japan Sea 1:65-96

Okutani T, Kubodera T, Jefferts K (1988) Diversity, distribution and ecology of gonatid squids in the subarctic Pacific: a review. Bull Ocean Res Inst Univ Tokyo 26:159-192

Parry M (2003) The trophic ecology of two ommastrephid squid species, Ommastrephes bartramii and Sthenoteuthis oualaniensis, in the north Pacific sub-tropical gyre. PhD dissertation, University of Hawaii-Manoa, Honolulu, HI

Parry M (2008) Trophic variation with length in two ommastrephid squids, Ommastrephes bartramii and Sthenoteuthis oualaniensis. Mar Biol 153:249-256

Partridge L, Green P (1985) Intraspecific feeding specializations and population dynamics. In: Sibly RM, Smith RH (eds) Behavioural ecology. Blackwell Scientific Publications, Oxford, p 207-226

Phillips KL, Nichols PD, Jackson GD (2003) Size relates dietary changes in the squid Moroteuthis ingens at the Falkland Islands: stomach contents and fatty-acids analyses. Polar Biol 26:474-485

R Development Core Team (2010) R: a language and environment for statistical computing. R Foundation for Statistical Computing, Vienna

Radchenko VI (1992) The role of squids in the pelagic ecosystem of the Bering Sea. Oceanology 32:762-767

Reum J, Essington TE (2008) Seasonal variation in the feeding 
guild structure of an estuarine demersal fish community. Estuaries Coasts 31:790-801

Roberts MJ, Sauer WHH (1994) Environment: key to understanding the South African chokka squid (Loligo vulgaris reynaudii) life cycle and fishery. Antarct Sci 6:249-258

Rocha F, Castro B, Gil MS, Guerra A (1994) The diets of Loligo forbesi and Loligo vulgaris (Cephalopoda: Loliginidae) in the northwestern Spanish Atlantic water. Sarsia 79: $119-126$

Rodhouse PG, Nigmatullin CM (1996) Role as consumers. Philos Trans R Soc Lond B Biol Sci 351:1003-1022

Rogers WH (1992) Quantile regression standard errors. Stata Tech Bull 9:16-19

Ruiz-Cooley RI, Gendron D, Aguiniga S, Mesnick S, Carriquiry JD (2004) Trophic relationships between sperm whales and jumbo squid using stable isotopes of $\mathrm{C}$ and $\mathrm{N}$. Mar Ecol Prog Ser 277:275-283

Ruiz-Cooley RI, Markaida U, Gendron D, Aguiniga S (2006) Stable isotopes in jumbo squid (Dosidicus gigas) beaks to estimate its trophic position: comparison between stomach contents and stable isotopes. J Mar Biol Assoc UK 86: $437-445$

Ruiz-Cooley RI, Villa EC, Gould WR (2010) Ontogenetic variation of $\delta^{13} \mathrm{C}$ and $\delta^{15} \mathrm{~N}$ recorded in the gladius of the jumbo squid Dosidicus gigas: geographic differences. Mar Ecol Prog Ser 399:187-198

Santos RA, Haimovici M (1998) Trophic relationships of the long-finned squid Loligo sanpaulensis on the southern Brazilian shelf. S Afr J Mar Sci 20:81-91

Scharf FS, Juanes F, Sutherland M (1998) Inferring ecological relationships from the edges of scatter diagrams: comparison of regression techniques. Ecology 79:448-460

Scharf FS, Juanes F, Roundtree RA (2000) Predator size-prey size relationships of marine fish predators: interspecific variation and effects of ontogeny and body size on trophicniche breadths. Mar Ecol Prog Ser 208:229-248

Serchuk FM, Rathjen WF (1974) Aspects of the distribution and abundance of the long-finned squid, Loligo pealei, between Cape Hatteras and Georges Bank. Mar Fish Rev 36:10-17

Shin YJ, Cury P (2004) Using an individual-based model of fish assemblages to study the response of size spectra to changes in fishing. Can J Fish Aquat Sci 61:414-431

Sinclair EH, Stabeno PJ (2002) Mesopelagic nekton and associated physics of the southeastern Bering Sea. Deep-Sea

Editorial responsibility: Yves Cherel,

Villiers-en-Bois, France
Res II 49:6127-6145

Smale MJ (1996) Cephalopods as prey. VI. Fishes. Philos Trans R Soc Lond B Biol Sci 351:1067-1081

Springer AM (1999) Summary, conclusions, and recommendations. In Loughlin TR, Ohtani K (eds) Dynamics of the Bering Sea. University of Alaska Sea Grant Press, AK-SG99-03, Fairbanks, AK, p 777-800

Stowasser G, Pierce GJ, Moffat CF, Collins MA, Forsythe JW (2006) Experimental study on the effect of diet on fatty acid and stable isotope profiles of the squid Lolliguncula brevis. J Exp Mar Biol Ecol 333:97-114

Sweeting CJ, Polunin NVC, Jennings S (2006) Effects of chemical lipid extraction and arithmetic lipid correction on stable isotope ratios of fish tissues. Rapid Commun Mass Spectrom 20:595-601

Takai N, Onaka S, Ikeda Y, Yatsy A, Kidokoro H, Sakamoto W (2000) Geographical variations in carbon and nitrogen stable isotope ratios in squid. J Mar Biol Assoc UK 80: $675-684$

> Tieszen LL, Boutton TW, Tesdahl KG, Slade NA (1983) Fractionation and turnover of stable carbon isotopes in animal tissues: implication for $\delta^{13} \mathrm{C}$ analysis of diet. Oecologia 57: 32-37

Vinogradov VI, Noskov AS (1979) Feeding of short-finned squid, Illex illecebrosus, and long-finned squid, Loligo pealei, off Nova Scotia and New England, 1974-1975. ICNAF Sel Pap 5:31-36

West JA, Sivak JG, Doughty MJ (1995) Microscopical evaluation of the crystalline lens of the squid (Loligo opalescens) during embryonic development. Exp Eye Res 60:19-35

Wistow GJ, Piatigorsky J (1988) Lens crystallins: the evolution and expression of proteins for a highly specialized tissue. Annu Rev Biochem 57:479-504

Woodward G, Ebenman B, Emmerson M, Montoya JM, Olesen JM, Valido A, Warrern PH (2005) Body size in ecological networks. Trends Ecol Evol 20:402-409

Zeidberg LD, Robinson BH (2007) Invasive range expansion by the Humboldt squid, Dosidicus gigas, in the eastern North Pacific. Proc Natl Acad Sci USA 104:12948-12950

Zeppelin TK, Tollit DJ, CAll KA, Orchard TJ, Gudmundson CJ (2004) Sizes of walleye pollock (Theragra chalcogramma) and Atka mackerel (Pleurogrammus monopterygius) consumed by the western stock of Steller sea lions (Eumetopias jubatus) in Alaska from 1998 to 2000. Fish Bull 102:509-521

Submitted: July 1, 2009; Accepted: June 28, 2010

Proofs received from author(s): September 3, 2010 